\title{
Sustainable Low-Cost Surfactin Production And Optimization By Bacillus Subtilis SNW3, Product Characterization, And Its Suitability For Plant Growth Promotion And Bioremediation of Crude Oil
}

\author{
Aiman Umar \\ Quaid-i-Azam University \\ Aneeqa Zafar \\ Quaid-i-Azam University \\ Hasina Wali \\ Quaid-i-Azam University \\ Meh Para Siddique \\ Quaid-i-Azam University \\ Muneer Ahmed Qazi \\ Shah Abdul Latif University \\ Afshan Hina Naeem \\ Quaid-i-Azam University \\ Zulfiqar Ali Malik \\ Shah Abdul Latif University
}

Safia Ahmed ( $\nabla$ safiamrl@yahoo.com)

Quaid-i-Azam University https://orcid.org/0000-0001-9773-6433

Original article

Keywords: Ecotoxicity, Bacillus subtilis SNW3, Surfactin, Bioremediation, Plant growth promotion

Posted Date: September 16th, 2021

DOI: https://doi.org/10.21203/rs.3.rs-847285/v1

License: (c) (i) This work is licensed under a Creative Commons Attribution 4.0 International License. Read Full License 


\section{Abstract}

At present time, every nation is absolutely concern about increase agricultural production and bioremediation of petroleum contaminated soil. Hence, with this intention in current study potent natural surfactant (surfactin) was evaluated for low-cost production by Bacillus subtilis SNW3, previously isolated from Fimkessar oil field, Chakwal Pakistan. The best results were obtained using substrates in combination (white beans powder ( $6 \% \mathrm{w} / \mathrm{v})$ plus waste frying oil $(1.5 \% \mathrm{w} / \mathrm{v})$ and $(0.1 \% \mathrm{w} / \mathrm{v})$ urea) with surfactin production of about $1.17 \mathrm{~g} / \mathrm{L}$ contributing $99 \%$ reduction in cost required for medium preparation. To the best of our knowledge, no single report is present describing surfactin production by Bacillus subtilis using white beans powder as a culture medium. Surfactin was confirmed as the principal product characterized by thin-layer chromatography (TLC) and Fourier-transform infrared spectroscopy (FTIR). Additionally, produced surfactin display great physicochemical properties of surface tension reduction value $(\mathrm{SFT}=28.8 \mathrm{mN} / \mathrm{m})$, significant oil displacement activity $(\mathrm{ODA}=4.9 \mathrm{~cm})$, excessive emulsification ability (E24=69.8\%), and attains critical micelle concentration (CMC) value at 0.58 $\mathrm{mg} / \mathrm{mL}$. Furthermore, surfactin exhibits excellent stability over an extensive range of $\mathrm{pH}$ (1-11), salinity (1$8 \%)$, temperature $\left(20-121^{\circ} \mathrm{C}\right)$ and even after autoclaving. Subsequently, surfactin produced proved suitable for bioremediation of crude oil ( $86 \%$ ) and as potent plant growth-promoting agent that significantly $(P<0.05)$ increase seed germination and plant growth promotion of chili pepper, lettuce, tomato and pea maximum at concentration of $(0.7 \mathrm{~g} / 100 \mathrm{~mL})$, proved as potential agent for agriculture and bioremediation processes by lowering economic and environmental stress.

\section{Introduction}

Environmental pollution due to petroleum products such as crude oil, diesel, and gasoline is of major ecological concern nowadays (Jimoh and Lin 2019). Major health problems in humans and animals occurred due to the release of petroleum and its by-products in a terrestrial and aquatic ecosystem because of having mutagenic, carcinogenic, and teratogenic effects (Yadav et al. 2016). Petroleumderived pollutants result in the limitation of phosphorus, iron, and nitrogen availability in agricultural soil (Nogueira et al. 2011). In today's challenging world enhanced agricultural productivity is the need of the hour to encounter human food demands. However, equally alarming is the damage of agricultural land by pollutants that needs bioremediation strategies. Hence, it is necessary for researchers to focus on remediation of all these issues. Biosurfactants are amphiphilic secondary metabolites that exhibit surface-active properties produced by bacteria, fungi, and yeast (Santos et al. 2016). Biosurfactantproducing microorganisms enhance plant growth with improvement in plant immunity against organic contaminants in the environment, furthermore, they are also efficient in alleviating stress responses in plants along with strengthening plant growth and development (Almansoory et al. 2019). Biosurfactants (lipopeptides) not only help in the detoxification of contaminated soil but also provoke induced systemic resistance (ISR) to provide defence responses for eradicating plant pathogens (Anjum et al. 2016). One of the positive influences of the use of lipopeptides in agriculture is its biocompatibility with living organisms (tawniczak et al. 2013). Hence, to minimize the initial dose of fertilizers by seed stimulation 
strategies and its equal distribution in the soil is made possible by biosurfactants (Krawczyńska et al. 2012). Many researchers verified that plant growth-promoting rhizobacteria (PGPR) positively enhance plant development after association with hydrocarbon-degrading bacteria in contaminated soil (Pawlik et al. 2017). Different plant growth-promoting traits include phosphate solubilization, siderophore production, hydrogen cyanide ( $\mathrm{HCN}$ ) production, indole acetic acid (IAA) production and systemic resistance induction (Benaissa 2019). Hence, for employing biosurfactants in agricultural, bioremediation and its application in other fields the reduction in cost needed for production are of absolute concern. Increase in awareness among public about the use of environment-friendly and sustainable green products demand new strategies development to cut down the production cost for replacement of toxic synthetic surfactants with biosurfactants (Shaban and Abd-Elaal 2017). Biosurfactants with numerous useful applications provide growing interest in diverse industrial sectors including food, medicine, cosmetics, and agriculture (Patil et al. 2014). However, the production cost is still high that depends on the availability of raw materials and downstream processing for scaleup at the industrial level (Akbari et al. 2018). Raw materials used for biosurfactant production accounts for about $50 \%$ of the final production cost. Better choice of raw material is a way to cut down the budget and make the process economically feasible. Unlike synthetic surfactants that produced from petroleum feed stock, biosurfactants could be produced using waste materials like agriculture waste (wheat bran), brewery waste and food waste by-products (potato peels and waste frying oil) that not only reduce cost but also helps in waste disposal in environment-friendly manner (Moshtagh et al. 2018; Vea et al. 2018). In the present study, we used potato peels powder, waste frying oil, molasses, and white beans powder as a lowcost substrate for production. Hence, with all the above intentions the current study was conducted to produce stable potent biosurfactants employing various cost-effective renewable resources and to evaluate the potential of produced surfactin for detoxification and management of crude oil contaminated soil and to promote plant growth and development.

\section{Materials And Methods}

\section{Microorganism and culture conditions}

In the current study, Bacillus subtilis SNW3, obtained from Microbiology Research Lab, Quaid-i-Azam University, Islamabad, was previously identified and isolated from contaminated soil of Fimkessar oil field, Chakwal, Pakistan (Malik and Ahmed 2012). The bacterial sample was cultured on nutrient agar plates (Yeast extract 2.0; Beef extract 1.0; Peptone 5.0; Sodium chloride 5.0; Agar $15 \mathrm{~g} / \mathrm{L}$ ) incubated for 24 h at $30^{\circ} \mathrm{C}$ to obtain separate pure colonies, stored for regular use at $4{ }^{\circ} \mathrm{C}$ and sub-cultured before use. The strain was preserved at $-80^{\circ} \mathrm{C}$ in nutrient broth (Peptone, 5; Meat extract, 1; Yeast extract, 2.0 and sodium chloride $\mathrm{g} / \mathrm{L}$ ) supplemented with $30 \%$ glycerol.

\section{Cost-effective substrates for biosurfactant production.}

For low cost biosurfactant production various cost-effective substrates were evaluated that includes: potato peels powder (total carbohydrate $68.7 \%$; starch $25 \%$; protein $18 \%$; non-starch polysaccharide $30 \%$; 
acid-soluble and acid-insoluble lignin $20 \%$ and nitrogen 1.3\%) (Liang et al. 2014), molasses (total sugars $62.3 \%$, sucrose $48.8 \%$, starch $0.33 \%$ and ash $13.1 \%$ ) (Palmonari et al. 2020 ), white beans powder (protein 15.62\%; carbohydrates $60.47 \%$; lipids $2.13 \%$; crude fibre 14.15\%) (Alayande et al. 2012), waste frying oil (palmitic acid 15.86\%; oleic acid 29.83\%; stearic acid $4.87 \%$ and linoleic acid $28.85 \%$ ) (Banani et al. 2015) and nitrogen sources : sodium nitrite, urea and ammonium nitrate while, conventional media yeast extract (protein $62.5 \%$; sugar $2.90 \%$; fat $0.10 \%$; ash $9.50 \%$ ) was used as control. Each carbon source listed above was designed to use individually, then selected substrates were used in different combinations to achieve an optimized medium composition. Molasses used in current study was obtained from Chashma Sugar Mills Limited in Dera Ismail Khan (Pakistan). Potato peels and waste frying oil were obtained from café located at Quaid-i-Azam University Islamabad (Pakistan). Whereas white beans were obtained from National Agricultural Research Council (NARC) Islamabad Pakistan.

\section{Inoculum}

Bacillus subtilis SNW3, streaked and stored on nutrient agar plates at $4{ }^{\circ} \mathrm{C}$ was used for inoculum preparation. A loop full of culture from a single isolated colony on plate added in $100 \mathrm{~mL}$ nutrient broth (Peptone, 5; Meat extract, 1; Yeast extract, 2.0 and sodium chloride, $5 \mathrm{~g} / \mathrm{L}$ ) incubated at $30^{\circ} \mathrm{C}$ for $48 \mathrm{~h}$ then seed culture from the nutrient broth was used as inoculum for all experiments.

\section{Production optimization, extraction, and partial purification of biosurfactant}

The strain Bacillus subtilis SNW3 was grown on conventional yeast extract media $(2 \% \mathrm{w} / \mathrm{v})$ and mineral salt medium (MSM) as described by Abouseoud et al. (2008) of given composition ( $\mathrm{g} / \mathrm{L}: \mathrm{KH}_{2} \mathrm{PO}_{4}, 2.0$; $\mathrm{K}_{2} \mathrm{HPO}_{4}, 4.0 ; \mathrm{FeSO}_{4} .7 \mathrm{H}_{2} \mathrm{O}, 0.025 ; \mathrm{MgSO}_{4} .7 \mathrm{H}_{2} \mathrm{O}, 1.0 ; \mathrm{KCl}, 0.2 ; \mathrm{NaCl}, 5.0 ; \mathrm{CaCl}_{2} .2 \mathrm{H}_{2} \mathrm{O}, 0.02$; and trace elements solution with composition of $\mathrm{MnSO}_{4} \cdot 4 \mathrm{H}_{2} \mathrm{O}, 1.78 ; \mathrm{ZnSO}_{4} .7 \mathrm{H}_{2} \mathrm{O}, 2.32 ; \mathrm{CuSO}_{4} \cdot 5 \mathrm{H}_{2} \mathrm{O}, 1.0 ; \mathrm{H}_{3} \mathrm{BO}_{3}$, 0.56; $\mathrm{KI}, 0.66$ and $\mathrm{NH}_{4} \mathrm{MoO}_{4} \cdot 2 \mathrm{H}_{2} \mathrm{O}, 0.39$ ) for evaluation of different environmental process parameters significant for biosurfactant production at various range of temperature $\left(15,30,37\right.$ and $\left.50^{\circ} \mathrm{C}\right), \mathrm{pH}(2,4,6$, $8,10,12)$, agitation speeds $(0,150$ and $250 \mathrm{rpm})$ and inoculum size $(0.5,1,1.5,2$ and 2.5$)$. After that carbon and nitrogen sources used to be screened out were used separately and in different combinations with MSM while yeast extract was used as control media. All designed experiments for substrate evaluation were run with $100 \mathrm{~mL}$ media in $250 \mathrm{~mL}$ Erlenmeyer flask with $\mathrm{pH}$ adjusted to $7.0 \pm 0.2$ and kept in a shaker for $96 \mathrm{~h}$ of incubation at $30^{\circ} \mathrm{C}$ and $150 \mathrm{rpm}$. The cell-free supernatant obtained after centrifugation at $12,000 \mathrm{rpm}$ was acidified up to $\mathrm{pH} 2.0$ with $1 \mathrm{M}$ hydrochloric acid (HCL) and kept overnight at $4{ }^{\circ} \mathrm{C}$. For crude surfactin, pelleted precipitates were extracted with chloroform/methanol (2:1) and concentrated by rotary evaporation (Marchut-Mikolajczyk et al. 2018).

\section{Assessment of biosurfactant production}

For estimation of biosurfactant production in cell-free supernatant, various methods like oil displacement activity (ODA) was performed according to the method of Morikawa et al. (2000), emulsification index (E24\%) was performed through a protocol of Cooper and Goldenberg (1987) and surface tension (SFT) was measured in mN/m by using KRUSS K20 digital Tensiometer (Kruss GmbH, Hamburg, Germany), 
performed at room temperature while using a platinum plate by Wilhelmy plate method according to the protocol given by manufacturer.

\section{Structural characterization of surfactin produced.}

For thin-layer chromatography (TLC) and Fourier transform infrared spectroscopy (FTIR) analysis, extracted form of crude biosurfactant was used while surfactin (from sigma) was taken as standard. Crude biosurfactant components were separated on Silica coated aluminium plates, silica gel 60 F254, MERCK Germany using chloroform: methanol: acetic acid (85:10:5, v/v) visualized under the wavelength of 254 and $365 \mathrm{~nm}$ to find retention factor (Rf) as described by Joy et al. (2017). For determination of surfactin functional groups $10 \mathrm{mg}$ crude biosurfactant was loaded and the spectrum was observed at the range of $4500-450 \mathrm{~cm}^{-1}$ using Tensor 27 (Bruker) FTIR spectrophotometer, equipped with ZnSe ATR (Marchut-Mikołajczyk et al. 2019).

\section{Functional characterization by Antibiogram of surfactin produced.}

For antibiogram analysis, the extracted surfactin $(10 \mathrm{mg} / \mathrm{mL})$ dissolved in demineralized water tested with two different antibiotics namely ciprofloxacin and clarithromycin $(1 \mathrm{mg} / \mathrm{mL})$ separately and in combination (surfactin:antibiotic 5:0.5 mg/mL) against Escherichia coli ATC 25922, poured at a concentration of $100 \mu \mathrm{L}$ and kept at $37^{\circ} \mathrm{C}$ for $24 \mathrm{~h}$ of incubation, finally examined by diameter $(\mathrm{mm})$ of the clear zone.

\section{Determination of critical micelles concentration (CMC) and critical micelle dilution (CMD)}

The $\mathrm{CMC}$ of the produced biosurfactant was determined by a change in surface tension reduction with biosurfactant solutions from 0.06 to $1.24 \mathrm{mg} / \mathrm{mL}$ prepared in demineralized water (Datta et al. 2018). For critical micelle dilution cell, free supernatant was diluted10-folds up to three levels (i.e. 10x, 100x, and 1000x) named as $\mathrm{CMD}^{-1}, \mathrm{CMD}^{-2}$, and $\mathrm{CMD}^{-3}$, respectively, and was analyzed by surface tension reduction values (Joshi et al. 2008a).

\section{Surfactin stability studies}

To elucidate the thermal stability of surfactin, the standard solutions were prepared at a concentration of $600 \mathrm{mg} / \mathrm{L}$ and incubated at different temperatures $\left(20-121^{\circ} \mathrm{C}\right)$ for $1 \mathrm{~h}$ then surface tension of test solutions was measured by the Wilhelmy plate method after cooling at room temperature. Furthermore, a stability test of produced surfactin at saline conditions was performed at different concentrations of sodium chloride $\mathrm{NaCl}(1-10 \%)$ and incubated at $30^{\circ} \mathrm{C}$ for 1 hour followed by the analysis of surface tension reduction. To determine $\mathrm{pH}$ effect on surfactin activity different buffer solutions were added to biosurfactant standard solution, adjusted to $\mathrm{pH} 1-5$ using citrate-phosphate buffer, $\mathrm{pH} 7$ using phosphate buffer, and pH 9-11 using carbonate-bicarbonate buffer solutions, and check for surface tension reduction after incubation at room temperature for 30 minutes (Goswami and Deka 2019).

\section{Exploration of surfactin for seeds germination and plant growth}


The seeds of tomato (Solanum Lycopersicum), pea (Pisum sativum), chili pepper (Capsicum annuum), and lettuce (Lactuca sativa) collected from NARC Islamabad, Pakistan were surface sterilized with 10\% $\mathrm{Na}$-hypochlorite for 20 minutes and then washed with sterile distilled water before use. The first seed germination experiment was conducted in petri plate containing 40 seeds positioned in filter paper and cotton soaked with four different concentrations $(0.1,0.3,0.5$, and $0.7 \mathrm{~g} / 100 \mathrm{~mL})$ of crude surfactin solution in distilled water while $100 \% \mathrm{v} / \mathrm{v}$ distilled water was used as a control. These plates were kept in yellow light at $25^{\circ} \mathrm{C}$ for 7 days after that relative seed germination (G, \%): (No. of seeds germinated (treatment) / No. of seeds germinated (control) $\times 100$ ) was calculated. After the germination test seeds treated with surfactin were transferred in pots (seeds without pre-treatment with biosurfactant were used as control) and kept in a greenhouse with temperature maintained between $20^{\circ} \mathrm{C}$ to $22^{\circ} \mathrm{C}$. Furthermore, for plant growth stimulation crude surfactin solution was added in pots at a concentration $(0.1,0.3,0.5$, and $0.7 \mathrm{~g} / 100 \mathrm{~mL}$ ) dissolved in distilled water thrice with 10 days interval while in control pots pure water was added. The emergence of plant seedlings was tested and checked for the morphological characteristic of plants like shoot length $(\mathrm{mm})$, root length $(\mathrm{mm})$, and dry weight $(\mathrm{g})$ of plants after 40 days (Huang et al. 2017).

\section{Bioremediation of crude oil through various design treatments}

Biodegradation efficiency of crude oil by Bacillus subtilis SNW3 was analyzed as illustrated by Rahman et al. (2002) with minor changes. An aliquot of $2 \mathrm{~mL}$ pre cultured Bacillus subtilis SNW3 was transferred into $250 \mathrm{~mL}$ of Erlenmeyer flask containing $100 \mathrm{~mL}$ mineral salt media with different concentrations of filter sterilized crude oil of $0.5,1,1.5$, and $2 \%(\mathrm{v} / \mathrm{v})$ as sole source of carbon and energy. For monitoring of abiotic loss of the crude oil an uninoculated media was used as control. All these flaks were incubated for 21 days at $200 \mathrm{rpm}$ and $35{ }^{\circ} \mathrm{C}$. For monitoring the bacterial growth in crude oil, the absorbance rate was detected at $(\mathrm{OD} 600 \mathrm{~nm})$ by using spectrophotometer while for biosurfactant production analysis surface tension reduction was examined by tensiometer. To estimate residual crude oil in media solvent extraction method by hexane was used after that left for evaporation in a pre-weight clean beaker. For quantification of remaining crude oil degradation gravimetric analysis was performed at different time intervals by following formula proposed by Patowary et al. (2017).

Hydrocarbon degradation $\%=$ Amount of crude oil degraded / Amount of crude oil added in the media $x$ 100

Surfactin suitability for removing hydrophobic pollutants from soil was analyzed by collecting $5-10 \mathrm{~cm}$ deep topsoil while following the protocol of Okop et al. (2012) and transported in a clean container to Microbiology laboratory of Quaid-i-Azam University Islamabad Pakistan. Crude oil used was collected from Pakistan petroleum limited. The soil collected was airdried and sieved with a $2 \mathrm{~mm}$ sieve after that $5 \%$ of crude oil was sprayed on the soil to pollute soil homogenically. The polluted soil was left undisturbed for 5 days and then divided into $200 \mathrm{~g}$ of equal parts and dispensed in pots. These pots were left undisturbed in the open air for a week. Then for conducting bioremediation experiments various designed treatments were established added twice throughout the remediation period: (TO) addition of 
distilled water as control, (T1) addition of cell-free supernatant containing surfactin, (T2) addition of cultured Bacillus subtilis SNW3 (T3) combination of cell free broth and cultured Bacillus subtilis SNW3, (T4) addition of tween 80 (T5) addition of fertilizer (NPK; 20-10-10) shown in (Table 1). The soil content of each pot was tilled twice a week for aeration with moisture maintenance at $60 \%$ and temperature of $28-30^{\circ} \mathrm{C}$, providing all those conditions that are appropriate for crude oil-degrading microbes present in the soil. After that soil samples of $10 \mathrm{~g}$ were collected from different areas of the plastic pots at the 30,60, 90th day and were gravimetrically determined using formula given by Ganesh and Lin (2009).

Table 1 Design treatments for removal of crude oil from contaminated soil by surfactin and Bacillus subtilis SNW3

\begin{tabular}{|c|c|c|c|c|}
\hline Treatments & Soil & Biological treatment & $\begin{array}{l}\text { Chemical } \\
\text { compounds }\end{array}$ & $\begin{array}{l}\text { Crude oil } \\
\text { concentration }\end{array}$ \\
\hline $\begin{array}{l}\text { Control } \\
\text { (T0) }\end{array}$ & $\begin{array}{l}200 \\
g\end{array}$ & & & $5 \%$ \\
\hline $\begin{array}{l}\text { Treatment } \\
1 \text { (T1) }\end{array}$ & $\begin{array}{l}200 \\
g\end{array}$ & $200 \mathrm{~mL}$ cell free surfactin broth & & $5 \%$ \\
\hline $\begin{array}{l}\text { Treatment } \\
2 \text { (T2) }\end{array}$ & $\begin{array}{l}200 \\
g\end{array}$ & $2 \%$ cultured broth $100 \mathrm{~mL}$ & & $5 \%$ \\
\hline $\begin{array}{l}\text { Treatment } \\
3 \text { (T3) }\end{array}$ & $\begin{array}{l}200 \\
g\end{array}$ & $\begin{array}{l}2 \% \text { cultured broth } 100 \mathrm{~mL}+100 \mathrm{~mL} \\
\text { cell free surfactin }\end{array}$ & & $5 \%$ \\
\hline $\begin{array}{l}\text { Treatment } \\
4 \text { (T4) }\end{array}$ & $\begin{array}{l}200 \\
g\end{array}$ & & $\begin{array}{l}10 \mathrm{mg} / \mathrm{kg} \text { of } \\
\text { tween } 80\end{array}$ & $5 \%$ \\
\hline $\begin{array}{l}\text { Treatment } \\
5 \text { (T5) }\end{array}$ & $\begin{array}{l}200 \\
\mathrm{~g}\end{array}$ & & $\begin{array}{l}0.8 \mathrm{~g} / \mathrm{kg} \text { of } \\
\text { fertilizer }\end{array}$ & $5 \%$ \\
\hline
\end{tabular}

\section{Statistical Analysis}

The obtained results were analyzed statistically with the use of STATISTICA software, one-way ANOVA (version 8.1). The difference between obtained results was analyzed by using the Tukeys test to find individual and control mean \pm standard deviation. Significance value was set at $p=0.05$ and $p$-values $\leq$ 0.05 were considered significant.

\section{Results}

\section{Substrate screening and optimization studies}

Biosurfactant production using Bacillus subtilis SNW3 was carried out using different carbon sources. Potato peels powder, molasses, white beans powder, and waste frying oil were evaluated as cheap media for surfactin production. The processing of potatoes produces starch-rich waste in form of potato peels, starch-rich wastewater, and unconsumable potato parts that could be used as a substrate for microbial 
production (Fox and Bala 2000). According to results obtained for optimization of culture conditions with $2 \%$ yeast extract media $30{ }^{\circ} \mathrm{C}$ temperature was considered as optimum for maximum surfactin production with an ODA value of $1.26 \mathrm{~cm}$. While other optimized cultural conditions were with $1 \%$ inoculum size, $150 \mathrm{rpm}$, and pH of 6 (Fig. 1). In the present study, no significant surfactin was produced at static condition that might be due to lack of oxygenation. At the end of the fermentation process, the obtained ODA values were $1.3,2.4,0.9$, and $1.8 \mathrm{~cm}$ for potato peels powder, white beans powder, sugar cane molasses, and waste frying oil media respectively with $2 \% \mathrm{w} / \mathrm{v}$ concentration, while the surface tension reduction values of all four biosurfactant solutions reduced from $72 \mathrm{mN} / \mathrm{m}$ to $41.3,33.6,41$ and $38.2 \mathrm{mN} / \mathrm{m}$ respectively. Though good emulsification values of all these biosurfactant solutions were obtained to about 55 to $57 \%$ (Fig. 2a). In the current study among nitrogen sources tested preferably urea act as a good nitrogen source shows surface tension reduction of $31.4 \mathrm{mN} / \mathrm{m}$ and ODA value of $2 \mathrm{~cm}$ (Fig. 2b). It has been reported that supplementation of peptone, urea, sodium nitrate, ammonium nitrate (Thanomsub et al. 2004), and meat extract (Bednarski et al. 2004) increased biosurfactant production. It was observed that white beans powder and waste frying oil resulted in significant oil displacement value. The white beans powder as a carbon source is more nutritious than other sources used due to high levels of suitable elements, especially proteins. Therefore, it is expected that white beans powder can be a suitable substrate instead of a conventional medium and induce microbial cells to regulate synthesis of enzymes synthases and other peptide moieties for more biosurfactant synthesis. Also, it has been found that combination of carbon sources is more nutritious that enhances biosurfactant synthesis. The final optimized combination media was (white beans powder $6 \%+$ waste frying oil $1.5 \mathrm{~mL}+$ urea $0.1 \mathrm{~g}$ ) with significant surfactin yield indicated ODA of $4.9 \mathrm{~cm}$, emulsification index of $69.8 \%$ and surface tension reduction value up to $28.8 \mathrm{mN} / \mathrm{m}$ (Fig. 2c). Trace elements added in media improve biosurfactant synthesis by acting as co-factor for enzymes.

As in this portion of the study, our focus was on the use of alternative non-conventional media for fermentation of biosurfactant production. It was observed that the concentration of surfactin produced was significantly high while using substrates in combination found to be maximum of $1.17 \mathrm{~g} / \mathrm{L}$ of surfactin with optimized media that was almost double while making a comparison with $0.56 \mathrm{~g} / \mathrm{L}$ produced with yeast extract control media (Fig. 2d). On average 1 kilogram of white beans powder with $240 \mathrm{~mL}$ of waste frying oil while $640 \mathrm{~g}$ of yeast extract media would be enough for preparing 16 liters of fermentation media that gave $1.17 \mathrm{~g} / \mathrm{L}$ of surfactin production. The cost required for the preparation of one liter of optimized low-cost media in the current study is 0.078 EUR, which is just $0.8 \%$ of one-liter synthetic yeast extract media cost 10.5 EUR. Hence utilizing these cost-effective nonconventional media instead of synthetic yeast extract contribute to a $99 \%$ reduction in cost required for medium preparation.

\section{Structural characterization of biosurfactant produced.}

Characterization of crude biosurfactant produced with final optimized media by Bacillus subtilis SNW3 was carried out by thin-layer chromatography (TLC) and Fourier transform infrared spectroscopy FTIR. Results obtained by TLC indicate the lipopeptide (surfactin) nature of the product with a band observed 
against standard surfactin having a retention factor (Rf) value of 0.68 as illustrated in (Fig. 3c). The FTIR spectra represent the presence of carboxylic functional groups and aliphatic amines the characteristic of the lipopeptide nature of biosurfactant produced. The FTIR spectra show a sharp peak at $1023 \mathrm{~cm}^{-1}$ and $972 \mathrm{~cm}^{-1}$ that corresponds to the presence of $\mathrm{C}-\mathrm{N}$ aliphatic amines in standard and crude biosurfactant (Fig. 3a, b). The peaks in FTIR spectra at 1450 and 1130 suggest the presence of stretching bands between carbon atoms and hydroxyl groups. The absorbance appears at $1762 \mathrm{~cm}^{-1}$ and $1757 \mathrm{~cm}^{-1}$ attributed to the vibrations due to the ester carbonyl group of peptide components. The peaks observed in FTIR spectra at 2942 and 2926 corresponds to the presence of $\mathrm{C}-\mathrm{H}$ bands (CH2- $\mathrm{CH} 3$ stretching). Another peak ranging from $3500-3200 \mathrm{~cm}^{-1}$ indicated presence of alcohols and phenols $\mathrm{O}-\mathrm{H}$ stretch, $\mathrm{H}$-bond. The spectra presented in the current study in comparison to standard surfactin from sigma suggested the presence of peptide moiety and aliphatic groups, a distinctive feature of lipopeptides.

\section{Functional characterization of surfactin by antibiogram activity}

In this study, we observed that surfactin produced by Bacillus subtilis SNW3 has an improved antimicrobial effect against Escherichia coli as compared to commercially available antibiotics. The maximum inhibitory zone was observed with the combined synergistic effect of surfactin with antibiotics. However, individual use of surfactin also displays a better antimicrobial effect as compared to antibiotics used. We observed that surfactin $(27 \mathrm{~mm})$, ciprofloxacin $(18 \mathrm{~mm})$, clarithromycin $(20 \mathrm{~mm})$ and surfactin in combination with antibiotics displayed $(30 \mathrm{~mm})$ inhibitory zone (Fig. 4). Therefore, obtained results demonstrated that surfactin has better antimicrobial properties than commercially available antibiotics and is significantly increased while surfactin and antibiotics are mainly used in combination. Biosurfactants in recent years provide a group of novel antimicrobial compounds. These natural compounds could be applied as safe and effective alternatives to conventional antibiotics. The antimicrobial effect of biosurfactants is due to their potential to form pores inside cell membrane (Gudiña et al. 2010). The results indicated that produced surfactin shows potential antimicrobial effect at a minimum concentration of $10 \mathrm{mg} / \mathrm{mL}$. Hence, these results demonstrate that produced surfactin not only provides new antimicrobial agents against resistant pathogenic strains but also needed to be used at lower concentrations than reported earlier that makes it economically feasible.

\section{Critical micelle concentration (CMC) and critical micelle dilution (CMD) determination}

The crude biosurfactant from Bacillus subtilis SNW3 dissolved in distilled water at different concentrations showed a reduction in surface tension of water from 72 to $36 \mathrm{mN} / \mathrm{m}$ with an increase in surfactin concentration. At the start decrease in surface tension was observed while surface tension set into constant value after concentration of $0.58 \mathrm{mg} / \mathrm{mL}$, indicated that the $\mathrm{CMC}$ had been obtained 
(Fig. 5a). For estimation of surfactin concentration produced in medium surfactin produced seems to be more competent that remains stable with surface tension reduction values from $29 \mathrm{mN} / \mathrm{m}$ to $32 \mathrm{mN} / \mathrm{m}$ after making 3-fold dilutions shown in (Fig. $5 \mathrm{~b}$ ). Interestingly surfactin produced during current study is seems to be more potent than reported earlier because only minimum concentration of $0.58 \mathrm{mg} / \mathrm{mL}$ was required to attain $\mathrm{CMC}$ value.

\section{Stability Studies}

The applicability of surfactin produced depends on behaviour it shows at different conditions of temperature, $\mathrm{pH}$, and salinity. The biosurfactant produced during the current study was found to be more stable after exposure to various temperatures ranges since no significant difference was detected for surface tension reduction values from 20 to $121^{\circ} \mathrm{C}$. The favourable surface tension reduction values were observed over a pH range of 1 to 11 , although in between $\mathrm{pH} 5$ to 7 surfactin produced was found to be more stable (Fig. 6). While with $\mathrm{pH}$ reduction at $\mathrm{pH} \mathrm{1}$, surface tension value raised slightly up to $35 \mathrm{mN} / \mathrm{m}$ which means that surfactin produced shows stability at acidic conditions but more effectively stable at alkaline ones. The decrease in stability of biosurfactants at acidic conditions might be due to the protonation of negative polar ends of surfactin molecules. Besides this, it was observed that produced surfactin was stable over a wide range of salt concentrations 1 to $8 \%$ appeared to be an increase in surface tension reduction values at high concentrations of salinity i.e $10 \% \mathrm{NaCl}$. It is assumed that reasons for decreased stability with more $\mathrm{NaCl}$ concentration could be due to ion-dipole interactions between salt and water that avoid solute molecules from reaching the interface for the reduction in surface tension.

\section{Effect of surfactin on seed germination}

In this study, Solanum lycopersicum (tomato), Pisum sativum (pea), Capsicum annuum (chili pepper), and Lactuca sativa (lettuce) were examined to demonstrate the effects of biosurfactant on seed germination. The current study depicts those seeds treated with different surfactin concentrations exhibit significantly $(P<0.05)$ better effects on germination as compared to control water. This increase in germination might be due to the reason that biosurfactant increases the permeability of seed coat to water that indirectly makes quicker the metabolic processes inside seeds. The best results for germination were obtained at higher concentrations of surfactin tested. Among all seeds tested significant $(P<0.05)$ stimulation was observed for chili pepper seeds, which shows almost double $51.7 \%$ germination at a concentration of $0.5 \mathrm{~g} / 100 \mathrm{~mL}$ in comparison to control $21.6 \%$ with MilliQ water. Similarly, tomato seeds show $68.75 \%$ germination at $0.7 \mathrm{~g} / 100 \mathrm{~mL}$ in comparison to control water (56.25\%) shown in (Fig. 7a). The germination of pea and lettuce seeds affected to some extent with not great difference observed as compared to control. According to da Silva et al. (2015) for facilitation of the germination process permeability of embryonic tissues is needed that makes easier the water entrance, 
which helps in the activation of metabolism. For increased germination of seeds, the released nutrients must diffuse at suitable rates from liquid-filled intercellular spaces into the seed coat.

\section{Effect of surfactin on the plant dry biomass}

The applied biosurfactant treatments also augmented the dry biomass of plants. The plants that arose after treating with different concentrations of surfactin displays higher biomass in comparison to control. This increase in biomass might be due to the enhanced production of phytohormones in plants and improved mineral solubilization in soil (Das and Kumar 2016). During the current study significant $(\mathrm{P}<$ 0.05 ) increase in weight was observed for chili pepper and lettuce that exhibit dry biomass of $0.21 \mathrm{~g}$ and $0.25 \mathrm{~g}$ at $0.7 \mathrm{~g} / 100 \mathrm{~mL}$ of surfactin used that is four times increase in relative to control $0.06 \mathrm{~g}$ of the seedling. Although for pea and tomato similarly a positive effect was noted with the addition of surfactin that significantly increase $(P<0.05)$ dry biomass at $0.7 \mathrm{~g} / 100 \mathrm{~mL}$ almost double in relative to control (Fig. 7b). Interestingly, in the present study positive effect of surfactin was observed for all seeds but maximum for chili pepper and lettuce seeds while analyzing germination and dry biomass.

\section{Effect of surfactin on root length}

Almost all surfactin concentrations tested showed an immense effect on root elongation. The plants treated with a higher concentration of $0.7 \mathrm{~g} / 100 \mathrm{~mL}$ of surfactin enhance root growth at maximum. The current study depicts that surfactin treatment exhibits significantly $(P<0.05)$ better elongation of seedling roots in lettuce, pea, and chili pepper almost two times greater than control. The tomato seedlings treated with surfactin also show an increase in root development (Fig. 7c). The increase in root elongation might be due to a decrease in the strength of wrapping tissues and seed coating resistance against the extension of the root axis that favours root development (da Silva et al. 2015). Another reason for the increase in root development by applying biosurfactants could be due to minimizing anaerobiosis conditions in the soil, the main cause of root stress (Shukry et al. 2013). Possible reasons that are hypothesized for increase in seed germination and plant growth after treating with surfactin are explained in a schematic way shown in (Fig. 8).

\section{Effect of surfactin on plant growth promotion}

All surfactin concentration tested shows significant effect on plant growth parameters. The chili pepper plants show a significant $(P<0.05)$ difference in height $8.06 \mathrm{~mm}$ after treatment with $0.7 \mathrm{~g} / 100 \mathrm{~mL}$ of surfactin almost double as compared to control (Fig. 7d). Whereas lettuce plants show a gradual increase in height with an increase in surfactin concentration that might be due to a slow reduction in resistance for the leaf axis region of the seed coat. Following our knowledge research conducted for the effect of biosurfactant on plant growth is not more and these results would provide a positive step in the future for growing such species without using toxic agrochemicals. The better plant development with the use of 
biological surfactants is due to increase nutrients bioavailability and emulsifying hydrophobic compounds in the soil a beneficial approach for plant growth-promoting microbes living in the rhizosphere (Marchut-Mikolajczyk et al. 2018). All four plant types of tested species with untreated control and treated with surfactin in comparison after 40 days of incubation are shown in (Fig. 9).

\section{Bioremediation of crude oil through surfactin}

Biosurfactants are used to emulsify hydrocarbons with the reduction in surface tension, enhancement of water solubility, and increasing oil displacement from soil particles (Andrade Silva et al. 2014; Geetha et al. 2018). Results obtained by the current study revealed that by use of biosurfactants oil-contaminated soil sediments could be remediated in an eco-friendly manner. The current study revealed that crude biosurfactants produced by Bacillus subtilis SNW3 effectively remove crude oil from the water and soil. In the present study, the pattern for Bacillus subtilis SNW3 growth on crude oil and MSM revealed that there was an increase in microbial growth trend up to 13 days of incubation whereas after that decline in growth was recorded while considering concentration maximum growth was observed for 1 and $1.5 \%$ of crude oil used. In the flasks amended with crude oil with increase in microbial growth the SFT value of the culture medium reduced from 72 to $29 \mathrm{mN} / \mathrm{m}$ which indicates the surfactin production (Fig. 10a). The simultaneous microbial growth and crude oil biodegradation with surfactin production in culture broth media indicates that various components of crude oil are utilized as substrates for surfactin production. This crude oil utilization by microbes and emulsification by produced biosurfactant boost up the biodegradation process (Antoniou et al. 2015). Mostly biosurfactants are considered as secondary metabolites but, some of biosurfactant molecules helps in microbial survival by aiding transport of nutrients towards microbial cells (Rodrigues et al. 2006a). However, for degradation of oil in MSM degradation percent was increased after every successive week till 21 days and significant values were observed for $1 \%$ of crude oil as ( $81.3 \%$ ) and ( $86 \%$ ) for $1.5 \%$ of crude oil (Fig. 10b, 11). After applying different strategies needed for bioremediation the residual crude oil content of each treatment revealed that biodegradation occurred at different extents. It was revealed that the combined strategy of bioaugmentation and biostimulation occurred in T3 shows more potential towards remediation of oil from contaminated soil. The highest reduction was observed with increase in time in all treatments after 90 days and maximum degradation percent observed for T3 treated with Bacillus subtilis SNW3 cultured microorganisms and surfactin (80.2\%), shows a significant difference from T0 control $(11.6 \%)$ with distilled water (Fig. 10c). The better bioremediation results (73.2\%) were obtained in $\mathrm{T} 1$ by stimulation of indigenous microbes with the addition of surfactin than those obtained in T2 by adding surfactin producing strain Bacillus subtilis SNW3 (63.8\%) that delay in T2 might be due to contaminant stress and time taken by microbial isolates to adopt new environment, while for T1 system facilitate degradation by emulsifying hydrocarbons for indigenous microorganisms who takes time only to produce enzymes needed for oil degradation. Tween 80 is considered to be more suitable for remediation of contaminated soil because of its low cost as compared to other non-ionic surfactants (Bautista et al. 2009). The Tween 80 improved soil washing and extraction of hydrocarbons from the soil, most successfully reported for polycyclic aromatic hydrocarbons PAHs (Gong et al. 2015). In the current study while making a 
comparison for bioremediation with chemical compounds it was observed that in T4 addition of Tween 80 shows $65.4 \%$ lower than treatments with biosurfactants that might be due to acidic conditions of soil generated by Tween 80 that is unsuitable for microbial growth (Liu et al. 2010). The oil reduction results obtained for T5 in which polluted soil treated with fertilizers showed (32.6\%) were lower than those obtained by other treatments (Fig. 10c). Less degradation of oil contaminated soil with addition of fertilizers might be due to absence of crude oil emulsification and only providing suitable nutritional components for oil degrader indigenous heterotrophic bacteria while in other case surfactin not only have ability for hydrocarbons emulsification but also possess good nutrients level. It was observed for all tested treatments that with passage of time after 60 days oil removal percent decreases that might be due to increase in toxic degradation by-products and decrease in the feeding material availability for microorganisms. In recent years, use of biosurfactants for the treatment of oil-contaminated soil is increased. Indigenous microbes that are normally present in oil-contaminated soil are mainly involved in the biodegradation of oil pollutants. Crude oil is a complex mixture of aliphatic and aromatic hydrocarbons that inhibits the uptake of carbon sources required for metabolism and growth. These oilcontaminated environments are treated with biosurfactants for enhancing hydrocarbons bioavailability to microbes present in the environment and to increase the fertility of agricultural soil shown in form of schematic presentation in (Fig. 12). In current study surfactin in combination with Bacillus subtilis SNW3 exhibits $80.2 \%$ removal of crude oil from contaminated soil higher than other chemical compounds tested for remediation.

\section{Discussion}

Biosurfactant production by using cost effective substrates produced by Bacillus subtilis SNW3 was previously studied by many researchers. An easy way to achieve cost-effective bioprocesses for surfactin production is by using a low-cost substrate. The use of waste frying oil as a sole source of carbon and energy for lipopeptide production by two Bacillus strains was previously reported by Md Badrul Hisham et al. (2019) that gave surface tension reduction values up to $36 \mathrm{mN} / \mathrm{m}$ these results are consistent with our study while Bacillus strain SNW3 growing on $2 \%$ waste frying oil shows $38 \mathrm{mN} / \mathrm{m}$ reduction value. De Lima et al. (2009) reported rhamnose production by Pseudomonas aeruginosa PACL strain cultivating on waste frying soybean oils indicated biosurfactant production with $100 \%$ emulsification index, surface tension reduction up to $26.0 \mathrm{mN} / \mathrm{m}$, and concentration of $3.3 \mathrm{~g} / \mathrm{L}$ while in the current study $56.3 \%$ emulsification was observed with $2 \%$ waste frying oil. Research conducted by Abdel-Mawgoud et al. (2008a) investigates surfactin production in a cost-effective manner with the use of $16 \%$ molasses and other trace elements that produce a surfactin yield of $1.12 \mathrm{~g} / \mathrm{L}$. However, it is also stated in many studies that the presence of hydrophobic substrate is essential for the production of biosurfactants (Karanth et al. 1999). According to literature different types of oils e.g., vegetable oils, waste cooking oil, glycerol, glucose, and diesel were screened out for biosurfactant production by fungal species $M$. circinelloides that shows $11.7 \mathrm{~cm}$ ODA with the use of waste cooking oil as carbon source. In another study conducted by Hasanizadeh et al. (2017) for biosurfactant production showed maximum biosurfactant production with the use of $8 \%(\mathrm{v} / \mathrm{v})$ waste cooking oil as carbon source. However, in these reported cases, these 
substrates were used separately while on the contrary in current study substrates were used in combination to increase production and reducing price of culture media. Likewise, some authors like Ohno et al. (1995) reported the use of Okara obtained after processing of ground soybeans as a substrate for lipopeptide iturin and surfactin production by Bacillus subtilis NB22. While Zhu et al. (2013) also investigated the use of soybean flour as a substrate for surfactin production by Bacillus amyloliquefaciens XZ-173. To the best of our knowledge, for economical biosurfactant production, only a few studies are conducted by using soybean, but no single study is present that shows the use of white beans powder as a substrate for low-cost production. The concentration of surfactin produced (about $1.17 \mathrm{~g} / \mathrm{L}$ ) was close to other reported values for biosurfactant production using cost effective substrates. Also, it was reported by Najafi et al. (2010) that $30^{\circ} \mathrm{C}$ is the optimum temperature for biosurfactant production that is in correspondence with results obtained in the current study. In the present study, no significant surfactin was produced at static condition that might be due to lack of oxygenation that is also reported in study conducted by Santos et al. (2014) for biosurfactant production by Candida lipolytica. In a previous study conducted by Hemlata et al. (2015) for biosurfactant production by Stenotrophomonas maltophilia NBS-11 shows maximum production at $\mathrm{pH}$ 7. Urea and ammonium nitrate have been already used and reported in literature as very cost-effective nitrogen source to produce biosurfactant by Artherobacter paraffineus and various other bacterial species (Karanth et al. 1999). Study conducted by Medeot et al. (2017) showed high yield of biosurfactant $(1.7 \mathrm{mg} / \mathrm{mL})$ while using $\mathrm{NH}_{4} \mathrm{NO}_{3}$ and glucose as substrate for production by Bacillus amyloliquefaciens MEP218. In the same way, combination of sucrose and $\mathrm{NH}_{4} \mathrm{NO}_{3}$ were used by Fernandes et al. (2016) and they reported high yield of biosurfactant ( $0.2 \mathrm{~g} / \mathrm{L}$ ) by Bacillus subtilis RI4914. Likewise, study conducted for surfactin production by Abdel-Mawgoud et al. (2008b) reported use of different carbon nitrogen sources and ultimate results showed maximum biosurfactant production by Bacillus subtilis $\mathrm{BS} 5$ while using $\mathrm{NaNO}_{3}$ and $\mathrm{NH}_{4} \mathrm{NO}_{3}$ as source of nitrogen. In our case, source of nitrogen and carbon plays an important role for surfactin production but amount of surfactin produced was almost double while using carbon/ nitrogen substrates in combination.

Primary characterization for surfactin was carried out by using TLC while using surfactin from sigma as standard. TLC can evaluate about biosurfactants composition, because of having different affinities of molecules to stationary and mobile phase through capillary action. Here our results for TLC of crude biosurfactant sample indicated presence of surfactin with an $\mathrm{Rf}$ value of 0.68 . These findings are consistent with other reported studies, where Rf value of 0.76 was observed by Cooper et al. (1981) for surfactin produced by Bacillus subtilis. Another report shows similar results for Rf values were observed by Arrebola et al. (2010) using Bacillus subtilis UMAF6619, UMAF6614, UMAF8561, UMAF6639 and Bacillus amyloliquefaciens PPCB004 for fengycin, iturin and surfactin as 0.9, 0.3 and 0.75 respectively. While FTIR results obtained were in accordance with TLC. The chemical structure of surfactin produced by Bacillus subtilis SNW3 was revealed by analyzing the crude extract using fourier transform infrared spectroscopy. FTIR analysis of crude biosurfactant produced by Bacillus subtilis SNW3 showed it contains alcohols and carboxylic acids (lipids) and peptide moieties (proteins). A similar pattern of FTIR aliphatic and peptide moieties was reported for the presence of lipopeptides by (Joshi et al. 2008b). The 
observed pattern of IR spectrum was very similar to spectrum obtained by de Faria et al. (2011) who reported the appearance of the stretch at $1721 \mathrm{~cm}^{-1}$ with FTIR analysis of biosurfactant produced by Bacillus subtilis isolate LSFM-05 that indicates the presence of lactone carbonyl group. Similar FTIR absorption spectra were reported in the literature for lipopeptide (Pereira et al. 2013). Based on results obtained for antibiogram in current study it was observed that produced surfactin shows potential antimicrobial effect at a minimum concentration of $10 \mathrm{mg} / \mathrm{mL}$. According to literature lipopeptides are reported for antimicrobial activity but in current study only less concentration of surfactin was required to show its antimicrobial effect. Likewise study conducted by Sambanthamoorthy et al. (2014) revealed antimicrobial activities against $A$. baumannii, E. coli, and $S$. aureus at a concentration of $25-50 \mathrm{mg} / \mathrm{mL}$. In current study results obtained proved the produced surfactin is of high efficiency since it shows ability to reduce surface tension of water from 72 to $36 \mathrm{mN} / \mathrm{m}$. The critical micelle concentration (CMC) is the minimum biosurfactant concentration needed to achieve lowest surface tension value after that point micellar aggregates formation starts (Ron and Rosenberg 2001). CMC is considered as important characteristic of surface-active agents for evaluation of their interfacial activity (Zhou et al. 2019b). As shown through obtained results the minimum SFT values $(36 \mathrm{mN} / \mathrm{m})$ was obtained at the surfactin concentration of $(0.58 \mathrm{mg} / \mathrm{mL})$ where $\mathrm{CMC}$ found to be more significant than previously obtained by Ghasemi et al. (2019) for lipoproteins with SFT reduction up to $(39 \mathrm{mN} / \mathrm{m})$ with $\mathrm{CMC}$ at concentration of $(2.7 \mathrm{mg} / \mathrm{mL})$. These results were also efficient as compared to commonly used synthetic surfactants sodium dodecyl sulfate (SDS) that attains CMC value at $2100 \mathrm{mg} / \mathrm{L}$ (Chen et al. 2006). These results suggest that superior results of $\mathrm{CMC}$ were obtained at $0.5 \mathrm{mg} / \mathrm{mL}$ for current surfactin produced over other reported $\mathrm{CMC}$ values of $2.7 \mathrm{mg} / \mathrm{mL}$.

After biosurfactant production purification strategies accounts for near $60 \%$ of total cost required for production. While considering economic value of the industry, most of biosurfactants are required either in crude form or in form of broth preparations. Therefore, for surfactin application produced by Bacillus subtilis SNW3 in crude extracted form without further purification steps was explored. Surfactin produced by Bacillus subtilis SNW3 exhibits excellent stability over an extensive range of $\mathrm{pH}(1-11)$, salinity (1$8 \%)$, temperature $\left(20-121^{\circ} \mathrm{C}\right)$ and even after autoclaving. In a previous study conducted by Purwasena et al. (2019) biosurfactant produced shows good stability regarding emulsification at a high temperature of $120^{\circ} \mathrm{C}, \mathrm{pH}$ of $4-10$, and $\mathrm{NaCl}$ concentration of $10 \%(\mathrm{w} / \mathrm{v})$ that are consistent with this study. Similarly, it was reported by Moussa et al. (2013) that while studying the stability of biosurfactant produced by Bacillus methylothrophicus and Rhodococcus equi strains found to be stable between $20-120^{\circ} \mathrm{C}$. The persistence of biosurfactant produced with reduced surface tension reduction values under alkaline conditions has also been reported by researchers in different studies (Rodrigues et al. 2006b; Gudina et al. 2010). Several other studies have been reported about stability of the biosurfactants at high salinity and temperature (Das and Kumar 2018; Hentati et al. 2019; Purwasena et al. 2019). The excellent stability of the produced surfactin at wide range of temperature, $\mathrm{pH}$ and salinity widens its applicability in several industrial sectors from food, pharmaceuticals, detergents, agricultural to enhanced bioremediation. 
In modern agricultural field use of bacterial biosurfactants plays an important role as they are ecofriendly and affordable. Lipopeptides derived from bacterial strains provide an ideal solution as they are eco-friendly, less toxic, remains active in harsh environments because of its more stability and are highly biodegradable in nature as compared to its synthetic counterparts (Lima et al. 2011). The genera Bacillus and Pseudomonas have been proven to be the major producers of biosurfactant molecules (Zhou et al. 2019a; Hussain and Khan 2020). For studying this the crude lipopeptide surfactin produced by Bacillus subtilis SNW3 at different concentrations were investigated on lettuce, pea, tomato and chilli for seed germination and plant growth parameters. We observed that treatment of plants with surfactin enhance not only seed germination but also faster the other parameters of plant growth (total plant dry weight, plant height, shoot length and root length) over the untreated control. These findings provide suggestions about surfactin that it bring about tolerance in host plant and also involved in increased resistance against pathogenesis in future in these plants, in accordance with results reported by (Raaijmakers et al. 2010; Nadeem et al. 2021). Similar results with an increase in plant biomass were observed by Liu et al. (2014). It was demonstrated by Cawoy et al. (2014) that surfactin produced by Bacillus isolates induce systemic resistance (ISR) which increases with an increase in surfactin concentration. Surfactin act as signalling molecule that provoke cannibalism and formation of matrix. These surfactin molecules stimulate outflow of potassium to encourage biofilm development (López et al. 2009). Treatment of seeds and plants with crude surfactin increased germination and plant growth parameters (height of plant, dry weight, root and shoot length) greater over those observed in untreated control. These findings revealed that when surfactin was added in higher concentration all these parameters improved with increasing concentration. Surfactin extract of Bacillus subtilis SNW3 could therefore be applicable in formulating biological control agents for diverse pathogens. Several researchers have reported the biosurfactant effect on seed germination, but to our knowledge, this is the first time reported about the use of given vegetable plants. Biopreparations are widely used nowadays for the enhancement of seed quality, to improve plant germination in contaminated soil, and also used as a nutrient for plants (Mukherjee et al. 2006). In this sense, due to the amphiphilic structure of biosurfactants, it acts on the external wrapping of seed tissues increases its permeability and facilitates germination. This property of biosurfactants having the potential to increase seed germination rate and high biocompatibility leads to effective application of surfactin produced by Bacillus subtilis SNW3 in agriculture, by reducing use of toxic agrochemicals. The increased plant growth parameters and defence provided by surfactin produced by Bacillus subtilis SNW3 may be due to more access to nutrients in soil and inhibition of plant pathogens. These surfactin molecules could be used as an alternative to chemical fertilizers and pesticides as biological stimulants and control agents with more the interesting results of the present study will create low-cost and environment-friendly plant growth promoting biological surfactants in agricultural fields. However, some research gaps are still required to be filled about mechanisms followed by biosurfactants concerning enhanced growth and development of plants.

Many reports are present about efficacy of biosurfactant produced by Bacillus species in oil recovery methods (Pereira et al. 2013), for bioremediation processes (Greenwell et al. 2016), in industrial sectors and degradation practices (Ismail et al. 2013). While degradation cationic portion of biosurfactant 
attracts bacterial membrane that is negatively charged and in contact with crude oil present in environment (Ferradji et al. 2014). Crude oil is composed of hydrophobic water insoluble compounds having diverse chain lengths of $n$-alkanes. Microorganisms involved degradation of low molecular weight hydrocarbon chains and synthesis of surface-active agents that makes culture media turbid after degradation of crude oil (Chandankere et al. 2014). By introducing microbial culture to contaminated site results in enhanced bioremediation through emulsification of hydrocarbons, solubilization and mobilization (Nievas et al. 2008). In this study Bacillus subtilis SNW3 was identified as efficient for bioremediation of crude oil and shows increased degradation as compared to other reported studies for degradation of crude oil (Sathishkumar et al. 2008). It was reported by Iwai et al. (2011) and Lee et al. (2018) that in addition to biosurfactants some other hydrocarbon-degrading indigenous microbes and their metabolic products are involved in the bioremediation of oil contaminants in the polluted environment. In a study conducted for application of microorganisms for total petroleum hydrocarbons (TPH) degradation by Rhodococcus sp. NJ2 and Pseudomonas sp. BP10 shows degradation percent of 49.5 and $60.6 \%$ respectively after 30 days incubation reported by Kumari et al. (2012) while in current study more significant biodegradation percent of $86 \%$ was observed after 21 days. Al-Wasify and Hamed (2014) explained that $P$. aeruginosa reveals about $77.8 \%$ of maximum degradation after incubation period of 28 days and temperature of $22^{\circ} \mathrm{C}$.

In a crude oil degradation study by Kumari et al., it was reported that two biosurfactant producing strain, namely, Pseudomonas sp. BP10 and Rhodococcus sp. NJ2 degraded 60.6 and $49.5 \%$ of TPH respectively when incubated for 30 days. According to results defined in the literature, $P$. aeruginosa produces biosurfactants that shows an ability to remove $49-54 \%$ of crude oil from contaminated sand (Bordoloi and Konwar 2008), while more than $85 \%$ of removal rates for diesel oil-contaminated sand samples were observed by Silva et al. (2010), but for petroleum-contaminated soil less than $20 \%$ removal was observed. Likewise, Nalini and Parthasarathi (2013) showed 92\% removal of used engine oil contaminated sand with biosurfactant produced by S. rubidae. Biosurfactant produced by S. marcescens UE015 confirmed recoveries of $59 \%$ and $78 \%$ of kerosene and crude oil, in comparison of $25 \%$ and $10 \%$ with distilled water used as control (Elemba et al. 2010). Bacterial strains efficiency regarding degradation depends on its degradative enzymes production. It was reported by Mishra and Singh (2012) that among degradative enzymes alkane hydroxylase results in degradation of n-hexadecane enzyme produced by Rhodococcus sp. NJ2 and $P$. aeruginosa PSA5. Genes involved in production of these degradative enzymes are reported in studies conducted by Whyte et al. (2002). Efficiency of bacterial degradative enzyme producing capabilities of the bacterial strain make them an efficient strain among other. Recently Mishra and Singh (2012), have reported that alkane hydroxylase enzyme play an important role in the degradation of $n$ hexadecane by bacterial strains $P$. aeruginosa PSA5 and Rhodococcus sp. NJ2. These enzymes play an important role in the hydrocarbon degradation and the respective genes that encode those enzymes were identified in recent studies (Whyte et al., 2002; Hassanshahian et al., 2012). Interesting point is that surfactin is mostly applied in biomedical field and only few reports are present that shows success story of surfactin in bioremediation of oil polluted environments. Biosurfactants have potential to degrade oil polluted environments in environment friendly manner, but problem is of cost competitiveness with 
chemical surfactants hence biosurfactant production on large scale using low-cost substrates is required to minimize production cost. The current study demonstrated the use of effective low-cost media for surfactin production by Bacillus subtilis SNW3. The possibility of utilizing waste frying oil in combination with low-cost white beans proved to be efficient to substitute yeast extract media and becomes worthwhile for its industrial-scale production. The surfactin obtained exhibited potential emulsifying and surface tension reducing capabilities with strong stability at a wide range of $\mathrm{pH}$, temperature, and salinity. In addition, surfactin showed higher potential for seed germination and plant growth of Capsicum annuum, Lactuca sativa, Solanum Lycopersicum, Pisum sativum, and removal of crude oil from contaminated soil, suggesting its potential application in environmental processes and agriculture.

\section{Abbreviations}

Thin-layer chromatography,(TLC); Fourier-transform infrared spectroscopy (FTIR); oil displacement activity (ODA); surface tension reduction value (SFT); excessive emulsification ability (E24); critical micelle concentration (CMC); induced systemic resistance (ISR); plant growth-promoting rhizobacteria (PGPR); hydrogen cyanide (HCN); indole acetic acid (IAA); National Agricultural Research Council (NARC); Mineral salt medium (MSM); retention factor (Rf); critical micelle dilution (CMD).

\section{Declarations}

\section{Ethics approval and consent to participate}

Not applicable

\section{Consent for publication}

Not applicable

\section{Availability of data and material:}

The data used to support the findings of this study are available from the corresponding author upon request. All the references carry DOI numbers where those can easily be accessed.

\section{Competing interests}

There is no competing interst.

\section{Funding}

No funding from externals is received for this research.

\section{Authors contributions}


AU and SA, Conception and study design; AU and AZ, carry out experimental work of study; AU, MPS and $H W, A H N$, testing and data analysis of study; SA, Supervision; AU, draft the manuscript; AU, MAQ, ZAM and SA, revised the manuscript. All authors read and approved the final manuscript.

\section{Acknowledgements}

Authors acknowledge National agriculture Research Council, Islamabad for providing seeds.

\section{Author's information:}

Aiman Umar ${ }^{1}$, Aneeqa Zafar ${ }^{1}$, Hasina Wali ${ }^{1,2}$, Meh Para Siddique ${ }^{4}$, Muneer Ahmed Qazi ${ }^{1,3}$, Afshan Hina Naeem ${ }^{1}$, Zulfiqar Ali Malik ${ }^{3}$, Safia Ahmed ${ }^{1 *}$

1 Department of Microbiology, Quaid-i-Azam University, Islamabad 45320, Pakistan

2 Department of Microbiology, University of Balochistan, Quetta 87300, Pakistan.

3 Department of Microbiology, Shah Abdul Latif University, Khairpur, Sindh 66111, Pakistan.

4 Department of Psychology, Quaid-i-Azam University, Islamabad 45320, Pakistan.

\section{References}

1. Abdel-Mawgoud AM, Aboulwafa MM, Hassouna NA-H (2008a) Optimization of surfactin production by Bacillus subtilis isolate BS5. J Applied Biochemistry Biotechnology 150:305-325. doi:https://doi.org/10.1007/s12010-008-8155-x

2. Abdel-Mawgoud AM, Aboulwafa MM, Hassouna NA-H (2008b) Optimization of surfactin production by Bacillus subtilis isolate BS5. J Applied Biochemistry Biotechnology 305-325 doi:https://doi.org/10.1007/s12010-008-8155-x

3. Abouseoud M, Yataghene A, Amrane A, Maachi R (2008) Biosurfactant production by free and alginate entrapped cells of Pseudomonas fluorescens. J Journal of Industrial Microbiology Biotechnology 35:1303-1308. doi:https://doi.org/10.1007/s10295-008-0411-0

4. Akbari S, Abdurahman NH, Yunus RM, Fayaz F, Alara OR (2018) Biosurfactants-a new frontier for social and environmental safety: a mini review. J Biotechnology Research Innovation 2:81-90. doi:https://doi.org/10.1016/j.biori.2018.09.001

5. Al-Wasify RS, Hamed SR (2014) Bacterial biodegradation of crude oil using local isolates. J International journal of bacteriology 2014. doi:https://doi.org/10.1155/2014/863272

6. Alayande L, Mustapha K, Dabak J, Ubom G (2012) Comparison of nutritional values of brown and white beans in Jos North Local Government markets. J African journal of biotechnology 11:1013510140. doi:10.5897/AJB11.3908

7. Almansoory AF, Hasan HA, Abdullah SRS, Idris M, Anuar N, Al-Adiwish WM (2019) Biosurfactant produced by the hydrocarbon-degrading bacteria: Characterization, activity and applications in 
removing TPH from contaminated soil. J Environmental technology innovation 14:100347. doi:https://doi.org/10.1016/j.eti.2019.100347

8. Andrade Silva NR et al (2014) Biosurfactant-and-bioemulsifier produced by a promising Cunninghamella echinulata isolated from caatinga soil in the northeast of Brazil. J International journal of molecular sciences 15:15377-15395. doi:https://doi.org/10.3390/ijms150915377

9. Anjum F, Gautam G, Edgard G, Negi S (2016) Biosurfactant production through Bacillus sp. MTCC 5877 and its multifarious applications in food industry. J Bioresource technology 213:262-269. doi:https://doi.org/10.1016/j.biortech.2016.02.091

10. Antoniou E, Fodelianakis S, Korkakaki E, Kalogerakis N (2015) Biosurfactant production from marine hydrocarbon-degrading consortia and pure bacterial strains using crude oil as carbon source. $\mathrm{J}$ Frontiers in microbiology 6:274. doi:https://doi.org/10.3389/fmicb.2015.00274

11. Arrebola E, Jacobs R, Korsten L (2010) Iturin A is the principal inhibitor in the biocontrol activity of Bacillus amyloliquefaciens PPCB004 against postharvest fungal pathogens. J Journal of Applied Microbiology 108:386-395. doi:https://doi.org/10.1111/j.1365-2672.2009.04438.x

12. Banani R, Youssef $S$, Bezzarga M, Abderrabba M (2015) Waste frying oil with high levels of free fatty acids as one of the prominent sources of biodiesel production. J J Mater Environ Sci 6:1178-1185

13. Bautista LF, Sanz R, Molina MC, González N, Sánchez D (2009) Effect of different non-ionic surfactants on the biodegradation of PAHs by diverse aerobic bacteria. J International Biodeterioration Biodegradation 63:913-922. doi:https://doi.org/10.1016/j.ibiod.2009.06.013

14. Bednarski W, Adamczak M, Tomasik J, Płaszczyk M (2004) Application of oil refinery waste in the biosynthesis of glycolipids by yeast. J Bioresource technology 95:15-18. doi:https://doi.org/10.1016/j.biortech.2004.01.009

15. Benaissa A (2019) Plant growth promoting rhizobacteria a review. J Algerian Journal of Environmental Science Technology 5:873-880

16. Bordoloi N, Konwar B (2008) Microbial surfactant-enhanced mineral oil recovery under laboratory conditions. J Colloids surfaces B: Biointerfaces 63:73-82. doi:https://doi.org/10.1016/j.colsurfb.2007.11.006

17. Cawoy $\mathrm{H}$ et al (2014) Plant defense stimulation by natural isolates of Bacillus depends on efficient surfactin production. J Molecular Plant-Microbe Interactions 27:87-100. doi:https://doi.org/10.1094/MPMI-09-13-0262-R

18. Chandankere R, Yao J, Cai M, Masakorala K, Jain AK, Choi MM (2014) Properties and characterization of biosurfactant in crude oil biodegradation by bacterium Bacillus methylotrophicus USTBa. J Fuel 122:140-148. doi:https://doi.org/10.1016/j.fuel.2014.01.023

19. Chen J, Wang X-j, Hu J-d, Tao S (2006) Effect of surfactants on biodegradation of PAHs by white-rot fungi. $J$ Huan jing ke xue $=$ Huanjing kexue 27:154-159

20. Cooper D, Macdonald C, Duff S, Kosaric N (1981) Enhanced production of surfactin from Bacillus subtilis by continuous product removal and metal cation additions. J Applied Environmental microbiology 42:408-412. doi:https://doi.org/10.1128/aem.42.3.408-412.1981 
21. Cooper DG, Goldenberg BG (1987) Surface-active agents from two Bacillus species. J Applied environmental microbiology 53:224-229. doi:https://doi.org/10.1128/aem.53.2.224-229.1987

22. da Silva VL, Lovaglio RB, Tozzi HH, Takaki M, Contiero J (2015) Rhamnolipids: a new application in seeds development. J Med Biol Sci Res 1:100-106

23. Das AJ, Kumar R (2016) Bioremediation of petroleum contaminated soil to combat toxicity on Withania somnifera through seed priming with biosurfactant producing plant growth promoting rhizobacteria. J Journal of environmental management 174:79-86. doi:https://doi.org/10.1016/j.biortech.2018.09.047

24. Das AJ, Kumar R (2018) Utilization of agro-industrial waste for biosurfactant production under submerged fermentation and its application in oil recovery from sand matrix. J Bioresource technology 260:233-240. doi:https://doi.org/10.1016/j.biortech.2018.03.093

25. Datta P, Tiwari P, Pandey LM (2018) Isolation and characterization of biosurfactant producing and oil degrading Bacillus subtilis MG495086 from formation water of Assam oil reservoir and its suitability for enhanced oil recovery. J Bioresource technology 270:439-448. doi:https://doi.org/10.1016/j.biortech.2018.09.047

26. de Faria AF et al (2011) Production and structural characterization of surfactin (C14/Leu7) produced by Bacillus subtilis isolate LSFM-05 grown on raw glycerol from the biodiesel industry. J Process Biochemistry 46:1951-1957. doi:https://doi.org/10.1016/j.procbio.2011.07.001

27. De Lima C, Ribeiro E, Servulo E, Resende M, Cardoso V (2009) Biosurfactant production by Pseudomonas aeruginosa grown in residual soybean oil. J Applied Biochemistry Biotechnology 152:156-168. doi:https://doi.org/10.1007/s12010-008-8188-1

28. Elemba OM, ljah UJJ, Chibunna M (2010) Isolation, characterization and MEOR ability of the biosurfactant produced from Serratia marcescens UEO15. J Glob J Adv Res 2:962-974

29. Fernandes P, Rodrigues E, Paiva F, Ayupe B, Mclnerney M, Tótola MJF (2016) Biosurfactant, solvents and polymer production by Bacillus subtilis RI4914 and their application for enhanced oil recovery. $\mathrm{J}$ Fuel 180:551-557. doi:https://doi.org/10.1016/j.fuel.2016.04.080

30. Ferradji FZ et al (2014) Naphthalene and crude oil degradation by biosurfactant producing Streptomyces spp. isolated from Mitidja plain soil (North of Algeria). J International Biodeterioration Biodegradation 86:300-308. doi:https://doi.org/10.1016/j.ibiod.2013.10.003

31. Fox SL, Bala GA (2000) Production of surfactant from Bacillus subtilis ATCC 21332 using potato substrates. J Bioresource technology 75:235-240. doi:https://doi.org/10.1016/S09608524(00)00059-6

32. Ganesh A, Lin J (2009) Diesel degradation and biosurfactant production by Gram-positive isolates. J African journal of Biotechnology 8 doi:https://doi.org/10.5897/AJB09.811

33. Geetha S, Banat IM, Joshi SJ (2018) Biosurfactants: Production and potential applications in microbial enhanced oil recovery (MEOR). J Biocatalysis Agricultural Biotechnology 14:23-32 doi: https://doi.org/10.1016/j.bcab.2018.01.010 
34. Ghasemi A, Moosavi-Nasab M, Setoodeh P, Mesbahi G, Yousefi G (2019) Biosurfactant production by lactic acid bacterium Pediococcus dextrinicus SHU1593 grown on different carbon sources: strain screening followed by product characterization. J Scientific reports 9:1-12. doi:https://doi.org/10.1038/s41598-019-41589-0

35. Gong X et al (2015) Remediation of PAH-contaminated soil at a gas manufacturing plant by a combined two-phase partition system washing and microbial degradation process. J Environmental Science Pollution Research 22:12001-12010. doi:https://doi.org/10.1007/s11356-015-4466-y

36. Goswami M, Deka S (2019) Biosurfactant production by a rhizosphere bacteria Bacillus altitudinis MS16 and its promising emulsification and antifungal activity. J Colloids Surfaces B: Biointerfaces 178:285-296. doi:https://doi.org/10.1016/j.colsurfb.2019.03.003

37. Greenwell M, Sarker M, Rahman PK (2016) Biosurfactant production and biodegradation of leather dust from tannery. J The Open Biotechnology Journal 10:312-325. doi:http://dx.doi.org/10.2174/1874070701610010312

38. Gudiña EJ, Rocha V, Teixeira J, Rodrigues L (2010) Antimicrobial and antiadhesive properties of a biosurfactant isolated from Lactobacillus paracasei ssp. paracasei A20. J Letters in applied microbiology 50:419-424. doi:https://doi.org/10.1111/j.1472-765X.2010.02818.x

39. Gudina EJ, Teixeira JA, Rodrigues LR (2010) Isolation and functional characterization of a biosurfactant produced by Lactobacillus paracasei. J Colloids Surfaces B: Biointerfaces 76:298304. doi:https://doi.org/10.1016/j.colsurfb.2009.11.008

40. Hasanizadeh P, Moghimi H, Hamedi J (2017) Biosurfactant production by Mucor circinelloides on waste frying oil and possible uses in crude oil remediation. J Water Science Technology 76:17061714 doi: https://doi.org/10.2166/wst.2017.338

41. Hemlata B, Selvin J, Tukaram K (2015) Optimization of iron chelating biosurfactant production by Stenotrophomonas maltophilia NBS-11. J Biocatalysis agricultural biotechnology 4:135-143. doi:https://doi.org/10.1016/j.bcab.2015.02.002

42. Hentati D et al (2019) Production, characterization and biotechnological potential of lipopeptide biosurfactants from a novel marine Bacillus stratosphericus strain FLU5. J Ecotoxicology environmental safety 167:441-449. doi:https://doi.org/10.1016/j.ecoenv.2018.10.036

43. Huang P, de-Bashan L, Crocker T, Kloepper JW, Bashan Y (2017) Evidence that fresh weight measurement is imprecise for reporting the effect of plant growth-promoting (rhizo) bacteria on growth promotion of crop plants. J Biology Fertility of Soils 53:199-208. doi:10.1007/s00374-0161160-2

44. Hussain T, Khan AA (2020) Bacillus subtilis HussainT-AMU and its Antifungal activity against Potato Black scurf caused by Rhizoctonia solanion seed tubers. J Biocatalysis Agricultural Biotechnology 23:101443. doi:https://doi.org/10.1016/j.bcab.2019.101443

45. Ismail W, Al-Rowaihi IS, Al-Humam AA, Hamza RY, El Nayal AM, Bououdina M (2013) Characterization of a lipopeptide biosurfactant produced by a crude-oil-emulsifying Bacillus sp. I-15. 
$\mathrm{J}$ International Biodeterioration Biodegradation 84:168-178.

doi:https://doi.org/10.1016/j.ibiod.2012.04.017

46. Iwai S, Johnson TA, Chai B, Hashsham SA, Tiedje JM (2011) Comparison of the specificities and efficacies of primers for aromatic dioxygenase gene analysis of environmental samples. J Applied environmental microbiology 77:3551-3557. doi:https://doi.org/10.1128/AEM.00331-11

47. Jimoh AA, Lin J (2019) Biosurfactant: A new frontier for greener technology and environmental sustainability. J Ecotoxicology Environmental safety 184:109607.

doi:https://doi.org/10.1016/j.ecoenv.2019.109607

48. Joshi S, Bharucha C, Jha S, Yadav S, Nerurkar A, Desai AJ (2008a) Biosurfactant production using molasses and whey under thermophilic conditions. J Bioresour Technol 99:195-199. doi:https://doi.org/10.1016/j.biortech.2006.12.010

49. Joshi S, Bharucha C, Jha S, Yadav S, Nerurkar A, Desai AJJBt (2008b) Biosurfactant production using molasses and whey under thermophilic conditions. 99:195-199

50. Joy S, Rahman PK, Sharma S (2017) Biosurfactant production and concomitant hydrocarbon degradation potentials of bacteria isolated from extreme and hydrocarbon contaminated environments. J Chemical Engineering Journal 317:232-241. doi:https://doi.org/10.1016/j.cej.2017.02.054

51. Karanth N, Deo P, Veenanadig N (1999) Microbial production of biosurfactants and their importance. J Current Science 77:116-126 doi. https://www.jstor.org/stable/24102919

52. Krawczyńska M, Kolwzan B, Rybak J, Gediga K, Shcheglova NS (2012) The Influence of Biopreparation on Seed Germination and Growth. J Polish Journal of Environmental Studies 21:1697-1702

53. Kumari B, Singh SN, Singh DP (2012) Characterization of two biosurfactant producing strains in crude oil degradation. J Process Biochemistry 47:2463-2471.

doi:https://doi.org/10.1016/j.procbio.2012.10.010

54. Ławniczak $Ł$, Marecik R, Chrzanowski $Ł$ (2013) Contributions of biosurfactants to natural or induced bioremediation. J Applied microbiology biotechnology 97:2327-2339. doi:https://doi.org/10.1007/s00253-013-4740-1

55. Lee DW et al (2018) Microbial community composition and PAHs removal potential of indigenous bacteria in oil contaminated sediment of Taean coast. Korea J Environmental pollution 234:503512. doi:https://doi.org/10.1016/j.envpol.2017.11.097

56. Liang S, McDonald AGJJoa, chemistry $f(2014)$ Chemical and thermal characterization of potato peel waste and its fermentation residue as potential resources for biofuel and bioproducts production. J Journal of agricultural food chemistry 62:8421-8429. doi:https://doi.org/10.1021/jf5019406

57. Lima TM, Procópio LC, Brandão FD, Leão BA, Tótola MR, Borges AC (2011) Evaluation of bacterial surfactant toxicity towards petroleum degrading microorganisms. J Bioresource technology 102:2957-2964. doi:https://doi.org/10.1016/j.biortech.2010.09.109 
58. Liu W, Hou J, Wang Q, Ding L, Luo Y (2014) Isolation and characterization of plant growth-promoting rhizobacteria and their effects on phytoremediation of petroleum-contaminated saline-alkali soil. $J$ Chemosphere 117:303-308. doi:https://doi.org/10.1016/j.chemosphere.2014.07.026

59. Liu Z-F, Zeng G-M, Wang J, Zhong H, Ding Y, Yuan X-Z (2010) Effects of monorhamnolipid and Tween 80 on the degradation of phenol by Candida tropicalis. J Process Biochemistry 45:805-809. doi:https://doi.org/10.1016/j.procbio.2010.01.014

60. López D, Vlamakis H, Losick R, Kolter R (2009) Cannibalism enhances biofilm development in Bacillus subtilis. J Molecular microbiology 74:609-618. doi:https://doi.org/10.1111/j.13652958.2009.06882.x

61. Malik Z, Ahmed S (2012) Degradation of petroleum hydrocarbons by oil field isolated bacterial consortium. J African Journal of Biotechnology 11:650-658. doi:https://doi.org/10.5897/AJB11.036

62. Marchut-Mikołajczyk O, Drożdżyński P, Januszewicz B, Domański J, Wrześniewska-Tosik K (2019) Degradation of ozonized tire rubber by aniline-Degrading Candida methanosorbosa BP6 strain. J Journal of hazardous materials 367:8-14. doi:https://doi.org/10.1016/j.jhazmat.2018.12.045

63. Marchut-Mikolajczyk O, Drożdżyński P, Pietrzyk D, Antczak T (2018) Biosurfactant production and hydrocarbon degradation activity of endophytic bacteria isolated from Chelidonium majus L. J Microbial cell factories 17:1-9. doi:https:// doi.org/10.1186/s12934-018-1017-5

64. Md Badrul Hisham NH, Ibrahim MF, Ramli N, Abd-Aziz S (2019) Production of biosurfactant produced from used cooking oil by Bacillus sp. HIP3 for heavy metals removal. J Molecules 24:2617. doi:https://doi.org/10.3390/molecules24142617

65. Medeot DB, Bertorello-Cuenca M, Liaudat JP, Alvarez F, Flores-Cáceres ML, Jofré E (2017) Improvement of biomass and cyclic lipopeptides production in Bacillus amyloliquefaciens MEP218 by modifying carbon and nitrogen sources and ratios of the culture media. J Biological control 115:119-128. doi:https://doi.org/10.1016/j.biocontrol.2017.10.002

66. Mishra S, Singh S (2012) Microbial degradation of $n$-hexadecane in mineral salt medium as mediated by degradative enzymes. J Bioresource technology 111:148-154. doi:https://doi.org/10.1016/j.biortech.2012.02.049

67. Morikawa M, Hirata Y, Imanaka T (2000) A study on the structure-function relationship of lipopeptide biosurfactants. J Biochimica et Biophysica Acta -Molecular Cell Biology of Lipids 1488:211-218. doi:https://doi.org/10.1016/S1388-1981(00)00124-4

68. Moshtagh B, Hawboldt K, Zhang B (2018) Optimization of biosurfactant production by Bacillus subtilis N3-1P using the brewery waste as the carbon source. J Environmental technology 40:33713380. doi:https://doi.org/10.1080/09593330.2018.1473502

69. Moussa L, Azeiz A, Ahmed Z (2013) Identification and characterization of biosurfactants produced by rodococcus equi and bacillus methlyotrophicus. J Biol Chem Environ Sci 8:341-358

70. Mukherjee S, Das P, Sen R (2006) Towards commercial production of microbial surfactants. J TRENDS in Biotechnology 24:509-515. doi:https://doi.org/10.1016/j.tibtech.2006.09.005 
71. Nadeem H, Niazi P, Asif M, Kaskavalci G, Ahmad F (2021) Bacterial strains integrated with surfactin molecules of Bacillus subtilis MTCC441 enrich nematocidal activity against Meloidogyne incognita. J Plant Biology doi: https://doi.org/10.1111/plb.13301

72. Najafı A, Rahimpour M, Jahanmiri A, Roostaazad R, Arabian D, Ghobadi Z (2010) Enhancing biosurfactant production from an indigenous strain of Bacillus mycoides by optimizing the growth conditions using a response surface methodology. J Chemical Engineering Journal 163:188-194. doi:https://doi.org/10.1016/j.cej.2010.06.044

73. Nalini S, Parthasarathi R (2013) Biosurfactant production by Serratia rubidaea SNAU02 isolated from hydrocarbon contaminated soil and its physico-chemical characterization. J Bioresource technology 147:619-622. doi:https://doi.org/10.1016/j.biortech.2013.08.041

74. Nievas M, Commendatore M, Esteves J, Bucalá V (2008) Biodegradation pattern of hydrocarbons from a fuel oil-type complex residue by an emulsifier-producing microbial consortium. J Journal of hazardous materials 154:96-104. doi:https://doi.org/10.1016/j.jhazmat.2007.09.112

75. Nogueira L, Rodrigues ACF, Trídico CP, Fossa CE, de Almeida EA (2011) Oxidative stress in Nile tilapia (Oreochromis niloticus) and armored catfish (Pterygoplichthys anisitsi) exposed to diesel oil. J Environmental monitoring assessment 180:243-255. doi:https://doi.org/10.1007/s10661-010-17859

76. Ohno A, Ano T, Shoda M (1995) Production of a lipopeptide antibiotic, surfactin, by recombinant Bacillus subtilis in solid state fermentation. J Biotechnology bioengineering 47:209-214. doi:https://doi.org/10.1002/bit.260470212

77. Okop I, Okorie F, Obadimu C (2012) Quantitative evaluation of the spatial distribution and penetration of liquid hydrocarbons in petroleum spilled soil. J Global Advanced Research Journal of Environmental Science Toxicology 1:152-161

78. Palmonari A et al (2020) Characterization of molasses chemical composition. J Journal of dairy science 103:6244-6249. doi:https://doi.org/10.3168/jds.2019-17644

79. Patil S, Pendse A, Aruna K (2014) Studies on optimization of biosurfactant production by Pseudomonas aeruginosa F23 isolated from oil contaminated soil sample. J Int J Curr Biotechnol 2:20-30

80. Pawlik M, Cania B, Thijs S, Vangronsveld J, Piotrowska-Seget Z (2017) Hydrocarbon degradation potential and plant growth-promoting activity of culturable endophytic bacteria of Lotus corniculatus and Oenothera biennis from a long-term polluted site. J Environmental Science Pollution Research 24:19640-19652 doi: https://doi.org/10.1007/s11356-017-9496-1

81. Pereira JF et al (2013) Optimization and characterization of biosurfactant production by Bacillus subtilis isolates towards microbial enhanced oil recovery applications. J Fuel 111:259-268. doi:https://doi.org/10.1016/j.fuel.2013.04.040

82. Purwasena IA, Astuti DI, Syukron M, Amaniyah M, Sugai Y (2019) Stability test of biosurfactant produced by Bacillus licheniformis DS1 using experimental design and its application for MEOR. J 
Journal of Petroleum Science Engineering 183:106383 doi:

https://doi.org/10.1016/j.petrol.2019.106383

83. Raaijmakers JM, De Bruijn I, Nybroe O, Ongena M (2010) Natural functions of lipopeptides from Bacillus and Pseudomonas: more than surfactants and antibiotics. J FEMS microbiology reviews 34:1037-1062. doi:https://doi.org/10.1111/j.1574-6976.2010.00221.x

84. Rahman K, Thahira-Rahman J, Lakshmanaperumalsamy P, Banat IM (2002) Towards efficient crude oil degradation by a mixed bacterial consortium. J Bioresource technology 85:257-261. doi:https://doi.org/10.1016/S0960-8524(02)00119-0

85. Rodrigues L, Banat IM, Teixeira J, Oliveira R (2006a) Biosurfactants: potential applications in medicine. J Journal of antimicrobial chemotherapy 57:609-618. doi:https://doi.org/10.1093/jac/dkl024

86. Rodrigues LR, Teixeira JA, van der Mei HC, Oliveira R (2006b) Isolation and partial characterization of a biosurfactant produced by Streptococcus thermophilus A. J Colloids surfaces B: Biointerfaces 53:105-112. doi:https://doi.org/10.1016/j.colsurfb.2006.08.009

87. Ron EZ, Rosenberg E (2001) Natural roles of biosurfactants: Minireview. J Environmental microbiology 3:229-236. doi:https://doi.org/10.1046/j.1462-2920.2001.00190.x

88. Sambanthamoorthy K, Feng X, Patel R, Patel S, Paranavitana C (2014) Antimicrobial and antibiofilm potential of biosurfactants isolated from lactobacilli against multi-drug-resistant pathogens. J BMC microbiology 14:1-9. doi:https://doi.org/10.1186/1471-2180-14-197

89. Santos DK et al (2014) Optimization of cultural conditions for biosurfactant production from Candida lipolytica. J Biocatalysis Agricultural Biotechnology 3:48-57. doi:https://doi.org/10.1016/j.bcab.2014.02.004

90. Santos DKF, Rufino RD, Luna JM, Santos VA, Sarubbo LA (2016) Biosurfactants: multifunctional biomolecules of the 21 st century. $J$ International journal of molecular sciences 17:401. doi:https://doi.org/10.3390/ijms17030401

91. Sathishkumar M, Binupriya AR, Baik SH, Yun SE (2008) Biodegradation of crude oil by individual bacterial strains and a mixed bacterial consortium isolated from hydrocarbon contaminated areas. $J$ CLEAN-Soil Air Water 92-96 doi:https://doi.org/10.1002/clen.200700042

92. Shaban SM, Abd-Elaal AA (2017) Studying the silver nanoparticles influence on thermodynamic behavior and antimicrobial activities of novel amide Gemini cationic surfactants. J Materials Science Engineering: C 76:871-885. doi:https://doi.org/10.1016/j.msec.2017.03.185

93. Shukry W, Al-Hawas G, Al-Moaikal R, El-Bendary M (2013) Effect of petroleum crude oil on mineral nutrient elements, soil properties and bacterial biomass of the rhizosphere of jojoba. J British journal of environment climate change 3:103-118

94. Silva S, Farias C, Rufino R, Luna J, Sarubbo L (2010) Glycerol as substrate for the production of biosurfactant by Pseudomonas aeruginosa UCP0992. J Colloids Surfaces B: Biointerfaces 79:174183. doi:https://doi.org/10.1016/j.colsurfb.2010.03.050 
95. Thanomsub B, Watcharachaipong T, Chotelersak K, Arunrattiyakorn P, Nitoda T, Kanzaki H (2004) Monoacylglycerols: glycolipid biosurfactants produced by a thermotolerant yeast, Candida ishiwadae. J Journal of applied microbiology 96:588-592. doi:https://doi.org/10.1111/j.13652672.2004.02202.x

96. Vea EB, Romeo D, Thomsen MJPC (2018) Biowaste valorisation in a future circular bioeconomy. J Procedia Cirp 69:591-596. doi:https://doi.org/10.1016/j.procir.2017.11.062

97. Whyte L, Smits T, Labbe D, Witholt B, Greer C, Van Beilen J (2002) Gene cloning and characterization of multiple alkane hydroxylase systems in Rhodococcus strains Q15 and NRRL B-16531. J Applied environmental microbiology 68:5933-5942. doi:https://doi.org/10.1128/AEM.68.12.5933-5942.2002

98. Yadav AK et al (2016) Isolation and characterization of biosurfactant producing Bacillus sp. from diesel fuel-contaminated site. J Microbiology 85:56-62. doi:https://doi.org/10.1134/S0026261716010161

99. Zhou D et al (2019a) Rhizosphere microbiomes from root knot nematode non-infested plants suppress nematode infection. J Microbial ecology 78:470-481. doi:https://doi.org/10.1007/s00248019-01319-5

100. Zhou J et al (2019b) High di-rhamnolipid production using Pseudomonas aeruginosa KT1115, separation of mono/di-rhamnolipids, and evaluation of their properties. J Frontiers in bioengineering biotechnology 7:245. doi:https://doi.org/10.3389/fbioe.2019.00245

101. Zhu Z, Zhang F, Wei Z, Ran W, Shen Q (2013) The usage of rice straw as a major substrate for the production of surfactin by Bacillus amyloliquefaciens XZ-173 in solid-state fermentation. J Journal of environmental management 127:96-102. doi:https://doi.org/10.1016/j.jenvman.2013.04.017

\section{Figures}



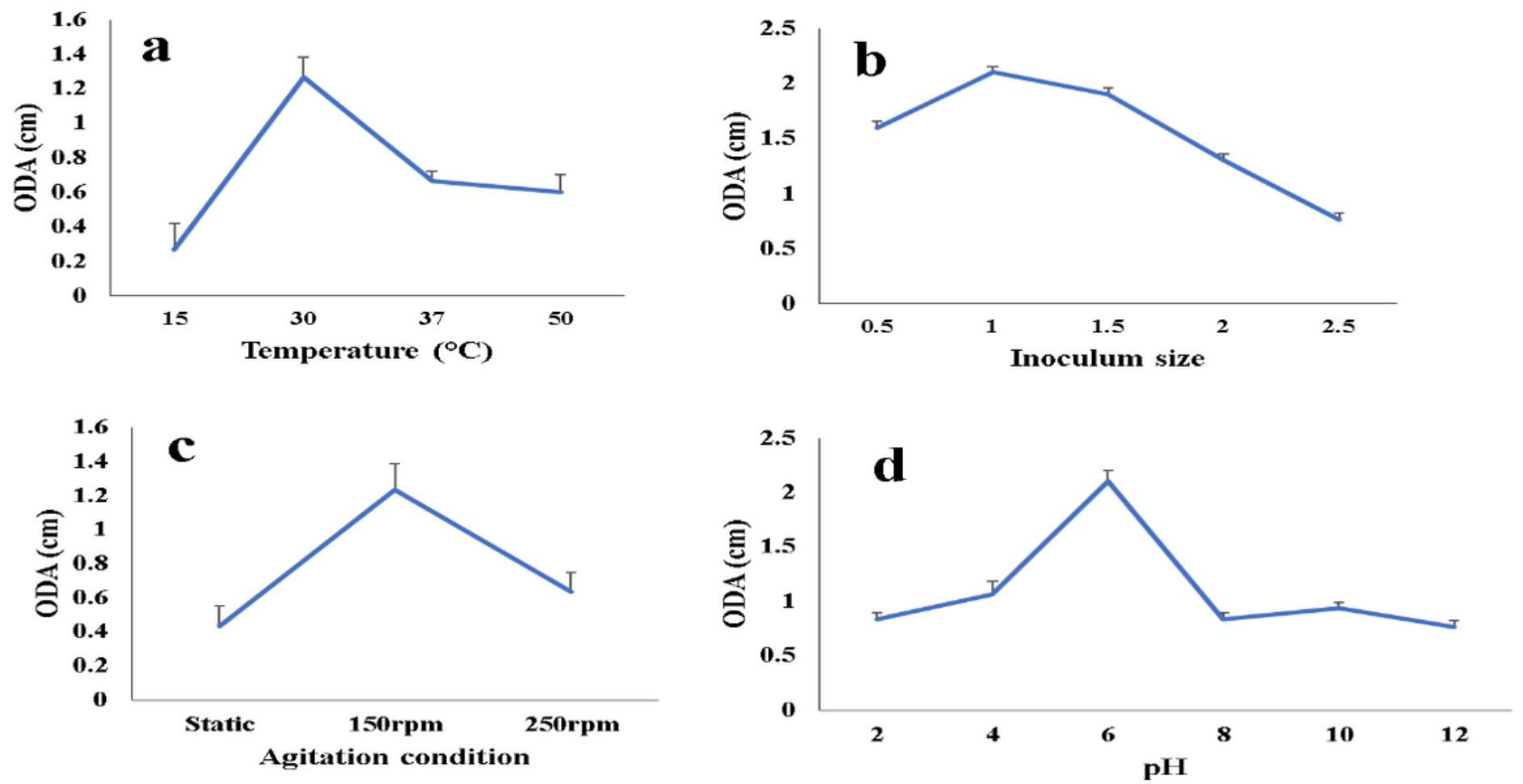

Figure 1

Effect of cultural conditions on ODA of surfactin produced by Bacillus subtilis SNW3 (a) Temperature (b) inoculum (c) agitation and (d) pH error bars represent \pm standard deviation that obtained after meaning the value of triplicate experiments. 


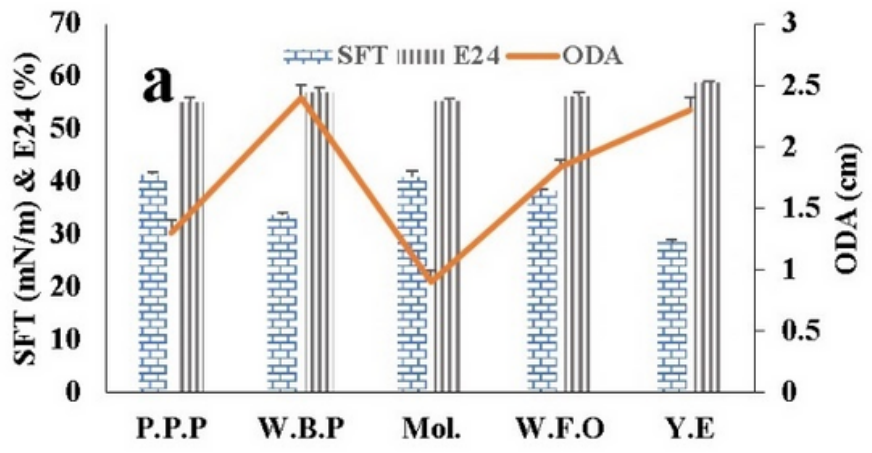

Carbon source $(2 \%, w / v)$

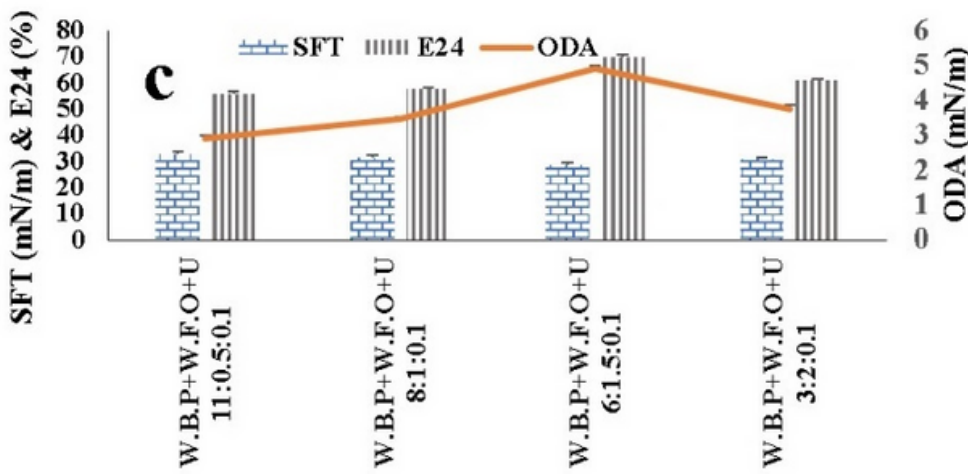

Combination of carbon and nitrogen sources

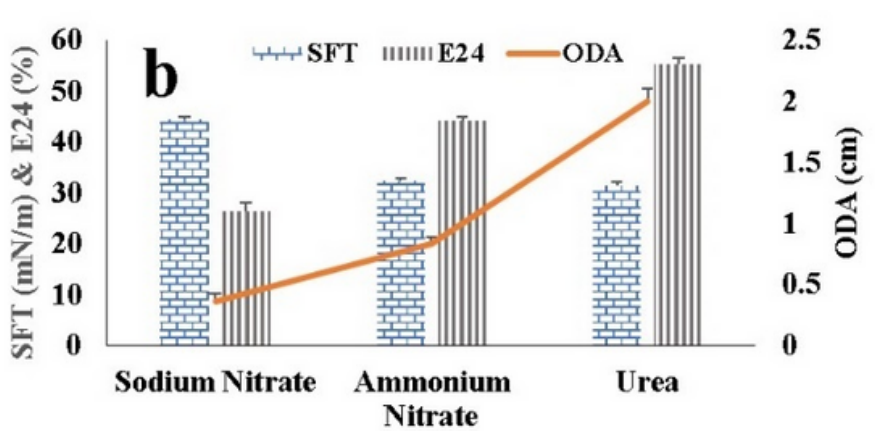

Nitrogen source $(0.1 \%, w / v)$

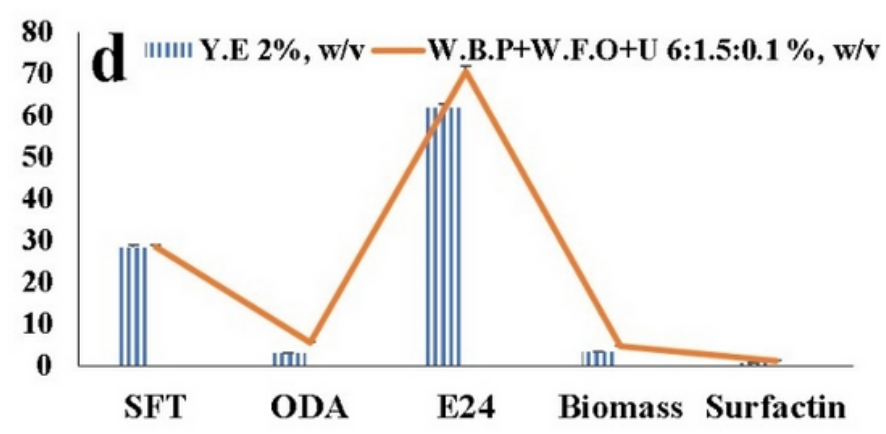

Production analysis under optimized conditions

Figure 2

SFT, E24 and ODA values for surfactin production by Bacillus subtilis SNW3 (a) with alternative carbon sources used individually (b) different nitrogen sources (c) with a combination of carbon and nitrogen energy sources and (d) production analysis of surfactin under optimized conditions with yeast extract as a reference, in shake flask fermentation at $30^{\circ} \mathrm{C}$. (Abbreviation: P.P.P Potato peels powder, W.B.P White beans powder, Mol. Molasses, W.F.O Waste frying oil and Y.E Yeast extract). 


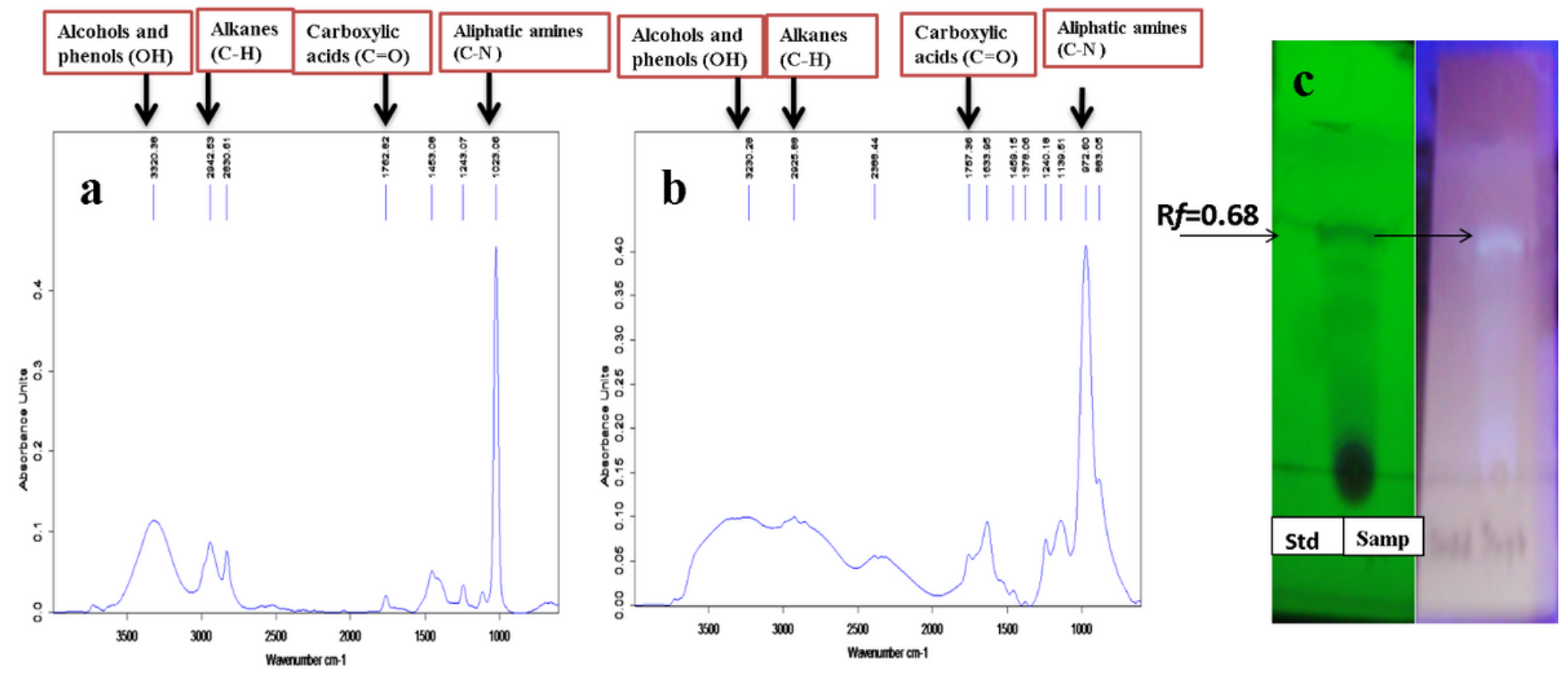

Figure 3

FTIR spectrum and TLC profile of crude surfactin produced by Bacillus subtilis SNW3 in comparison to standard surfactin show as (a) FTIR of standard surfactin (b) FTIR of crude extract (c) TLC profile.

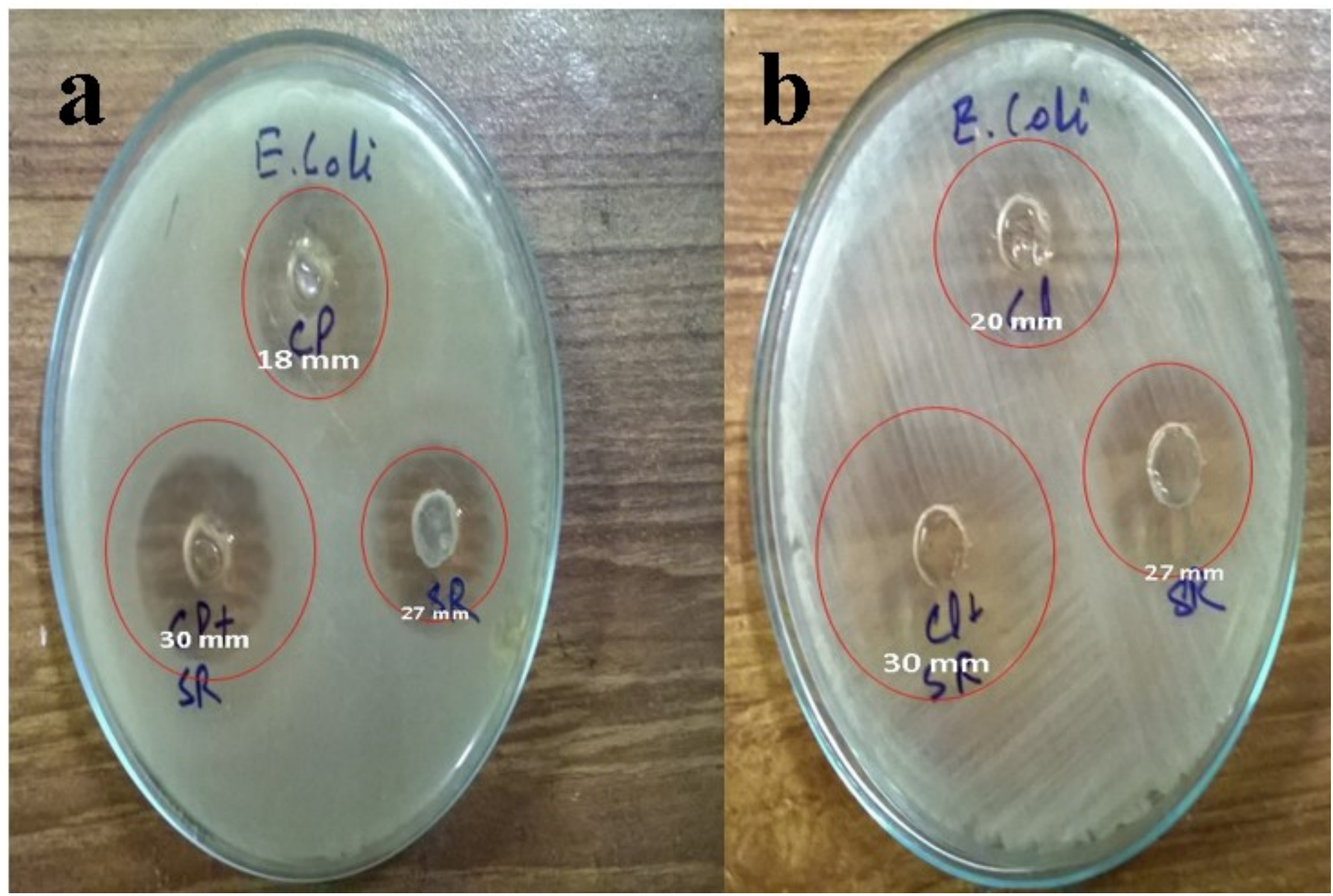


Figure 4

Antibiogram of surfactin produced with antibiotics (a) ciprofloxacin and (b) clarithromycin tested against Escherichia coli.
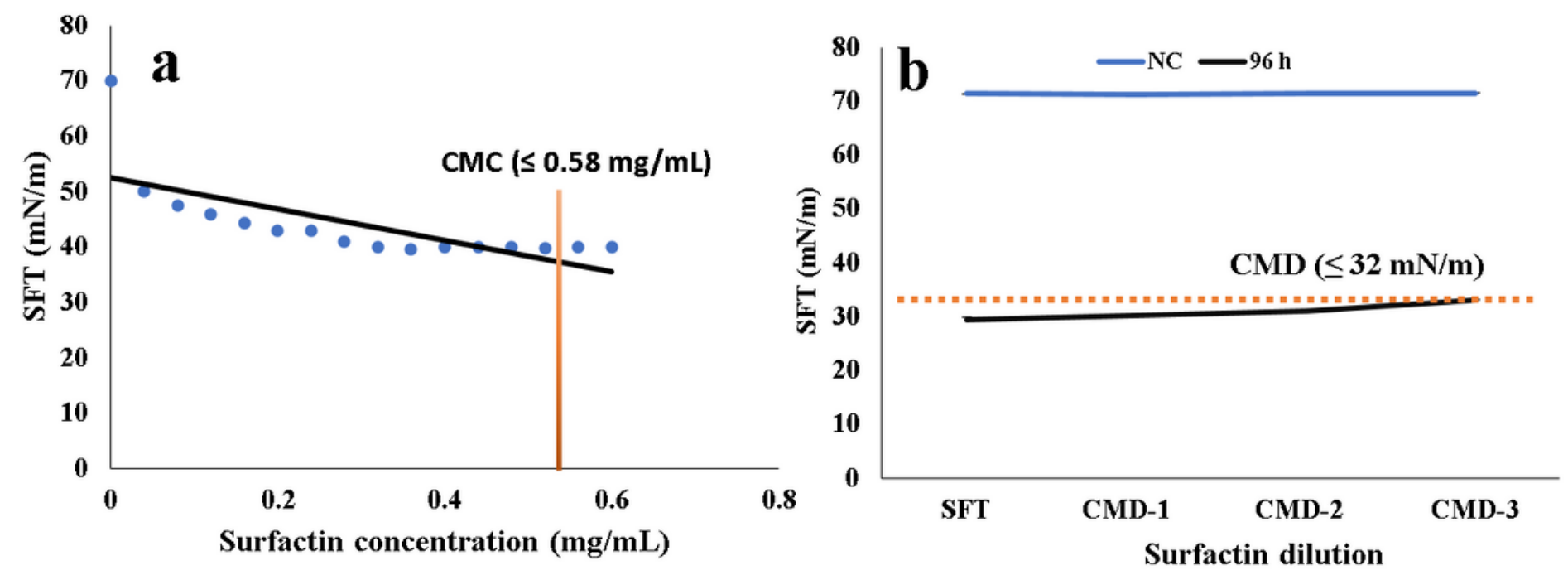

Figure 5

Surfactin analysis by (a) critical micelles concentration (CMC) and (b) critical micelles dilution (CMD); produced by Bacillus subtilis SNW3 about SFT measurement under optimized conditions.

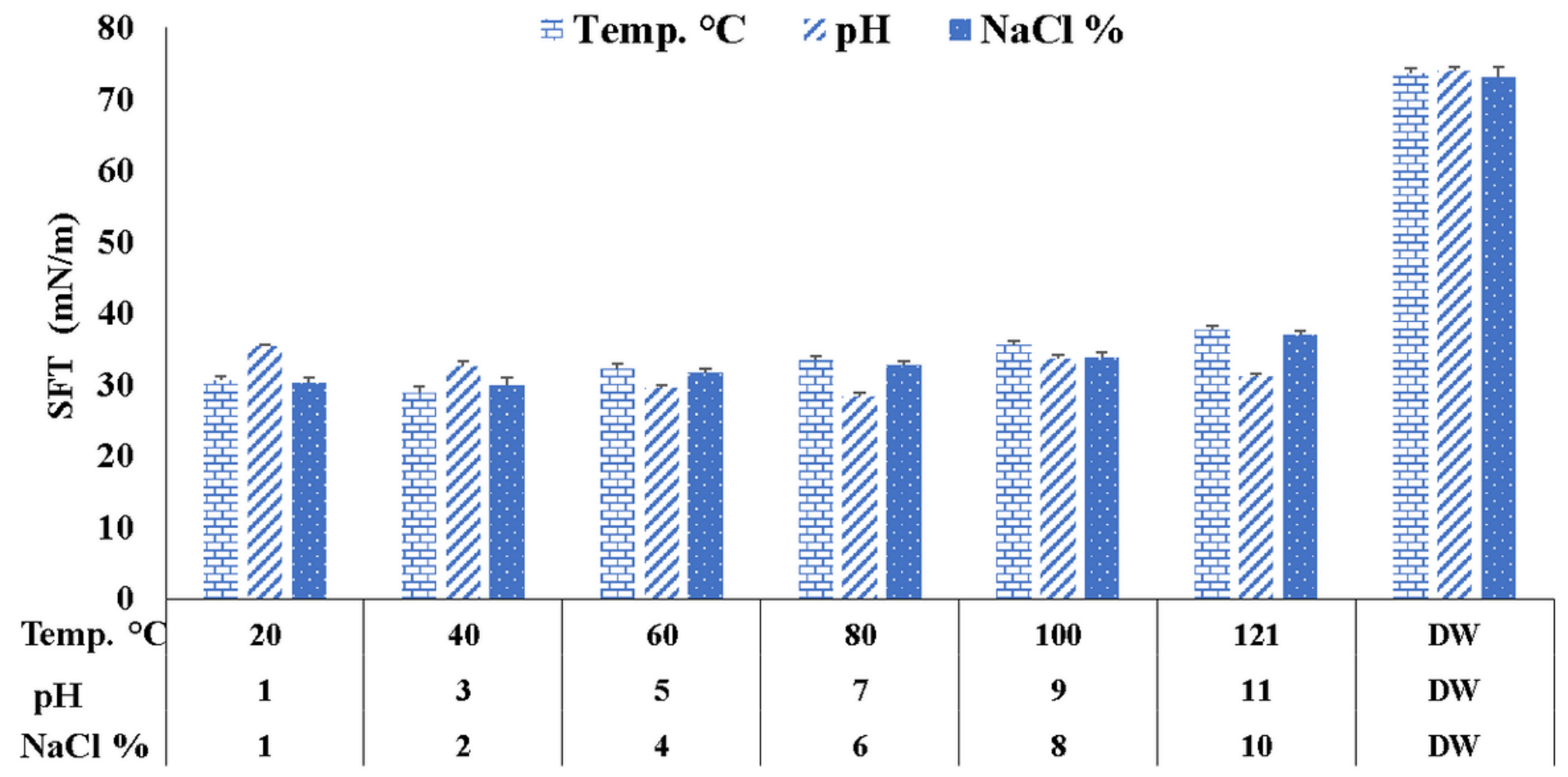

Figure 6 
Stability of crude surfactin on various environmental factors like temperature ranges $20-121^{\circ} \mathrm{C}, \mathrm{NaCl}$ conc. $1-10 \%(\mathrm{w} / \mathrm{v})$ and $\mathrm{pH}$ ranges 1-11 (Abbreviation: DW distilled water, Temp Temperature, $\mathrm{NaCl}$ Sodium Chloride).
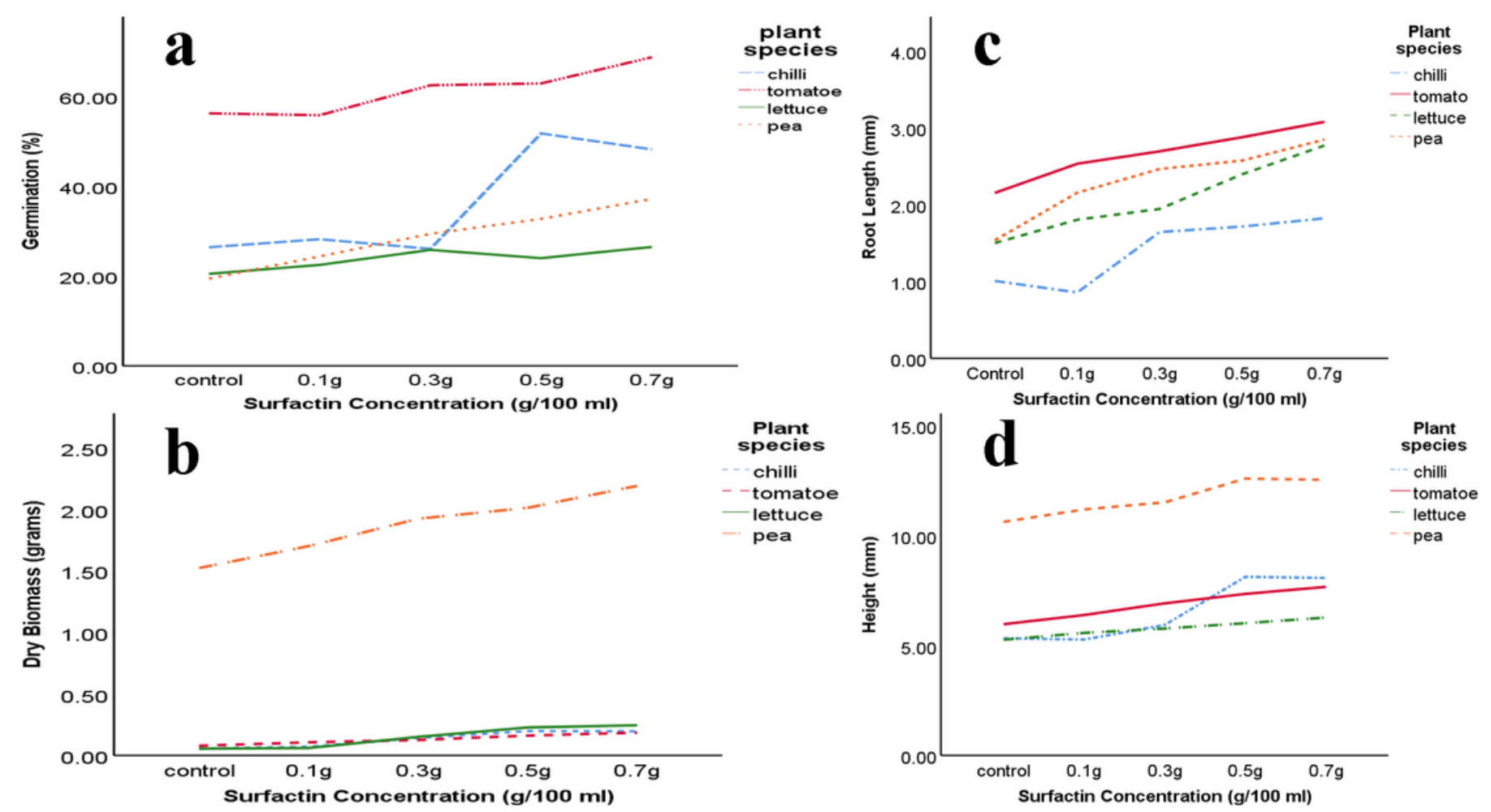

Figure 7

Effect of surfactin obtained from Bacillus subtilis SNW3 cultivated on white beans powder and waste frying oil on (a) germination of seeds (b) dry biomass of plant (c) root length and (d) height of plants. 


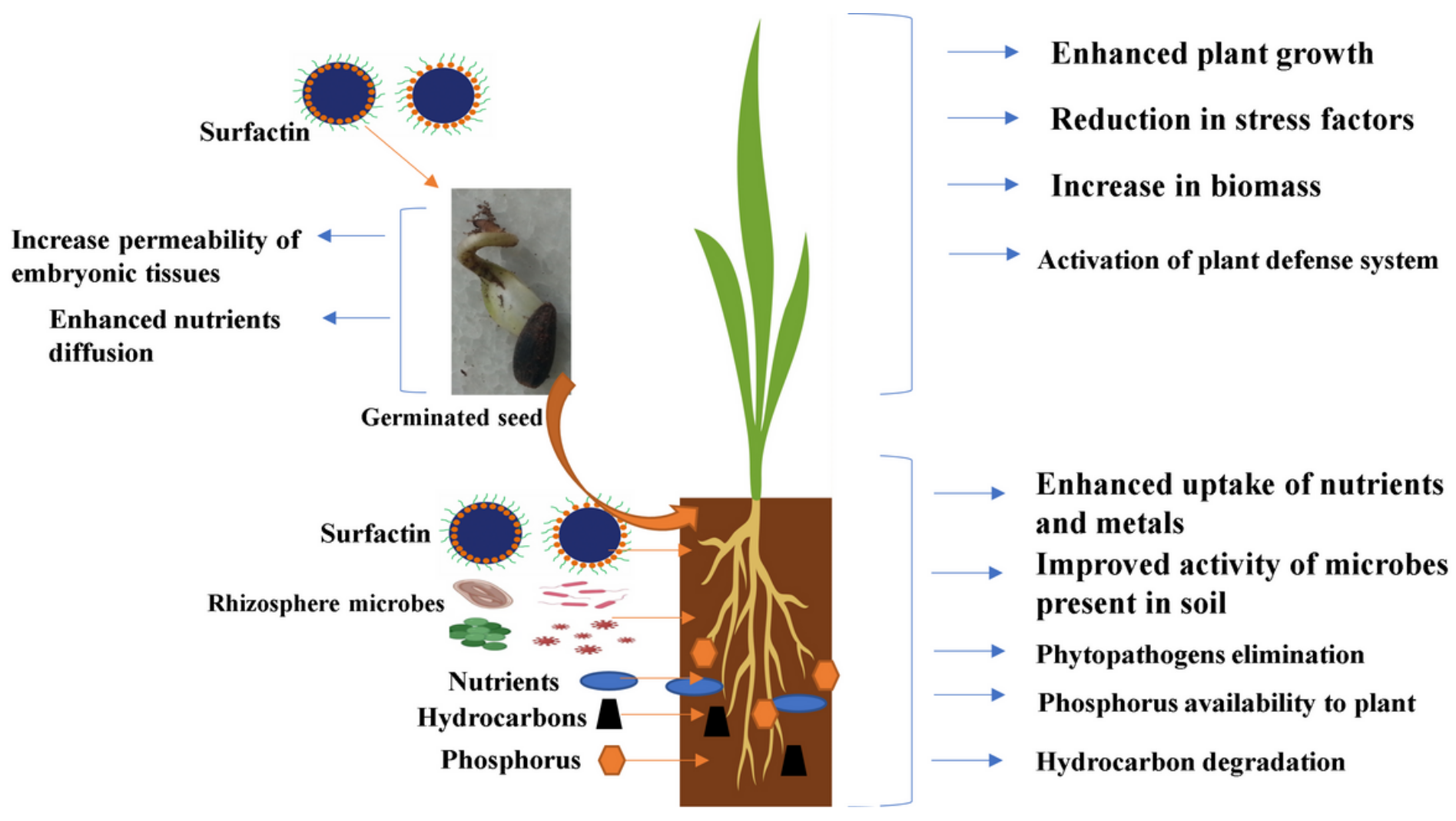

Figure 8

Diagrammatic explanation of possible effects of surfactin on hypothetical base on seed germination and plant growth promotion. 


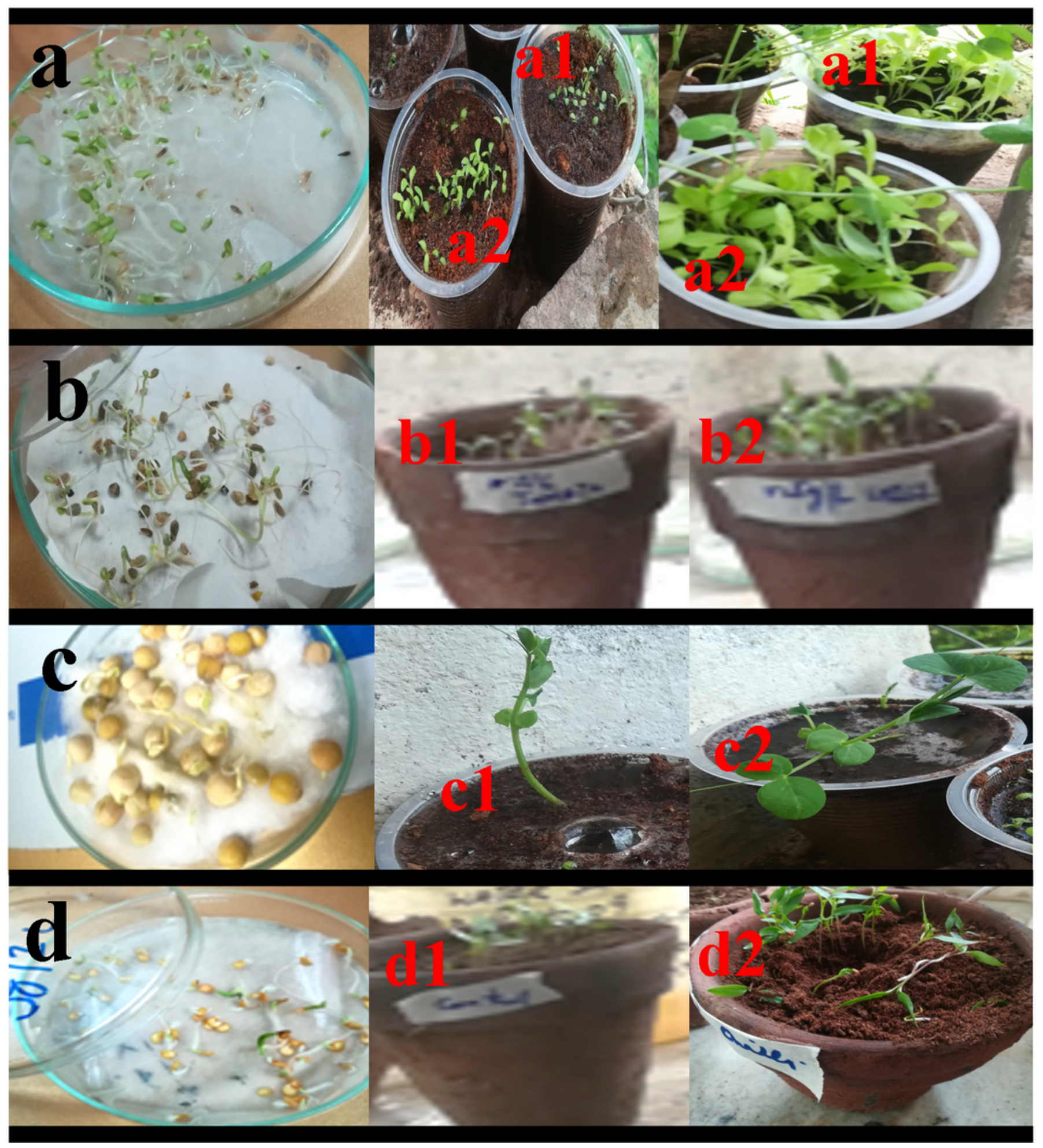

Figure 9

The growth of (a) lettuce, (b) tomato, (c) beans and (d) chilli plants while showing seeds with maximum germination and making comparison $(\mathrm{a} 1, \mathrm{~b} 1, \mathrm{c} 1, \mathrm{~d} 1)$ of plants with untreated control and $(\mathrm{a} 2, \mathrm{~b} 2, \mathrm{c} 2, \mathrm{~d} 2)$ effect on plants treated with surfactin after 40 days. 


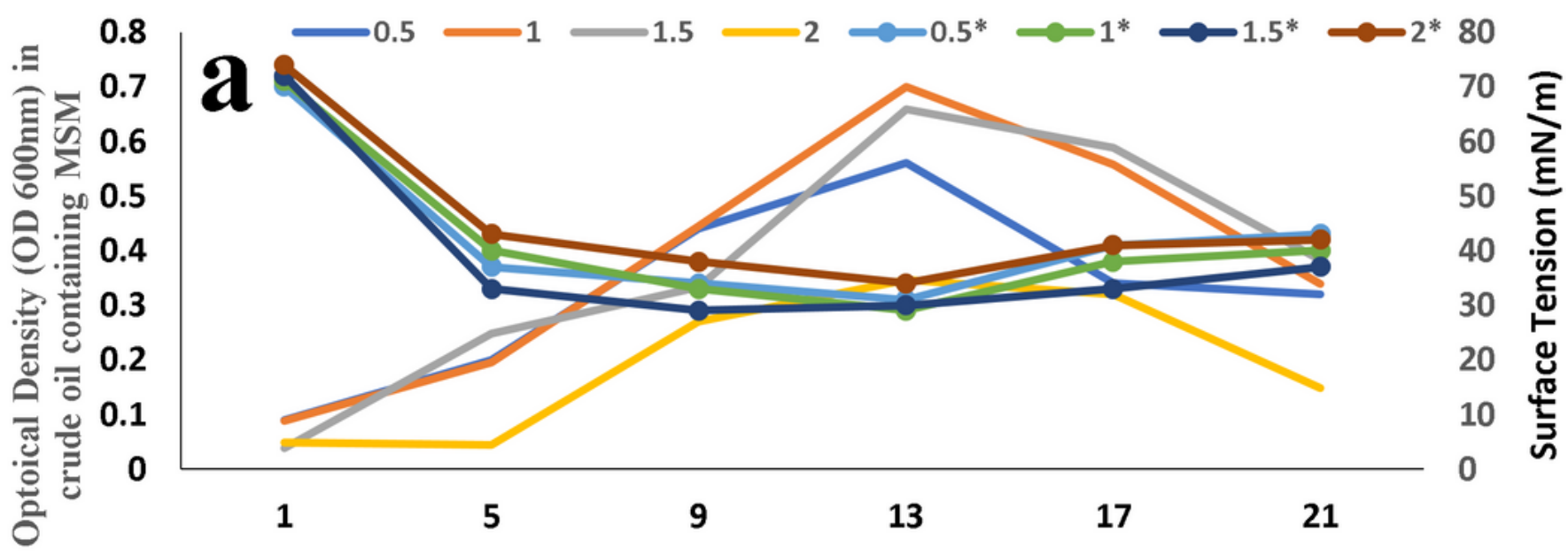

Time (Days)
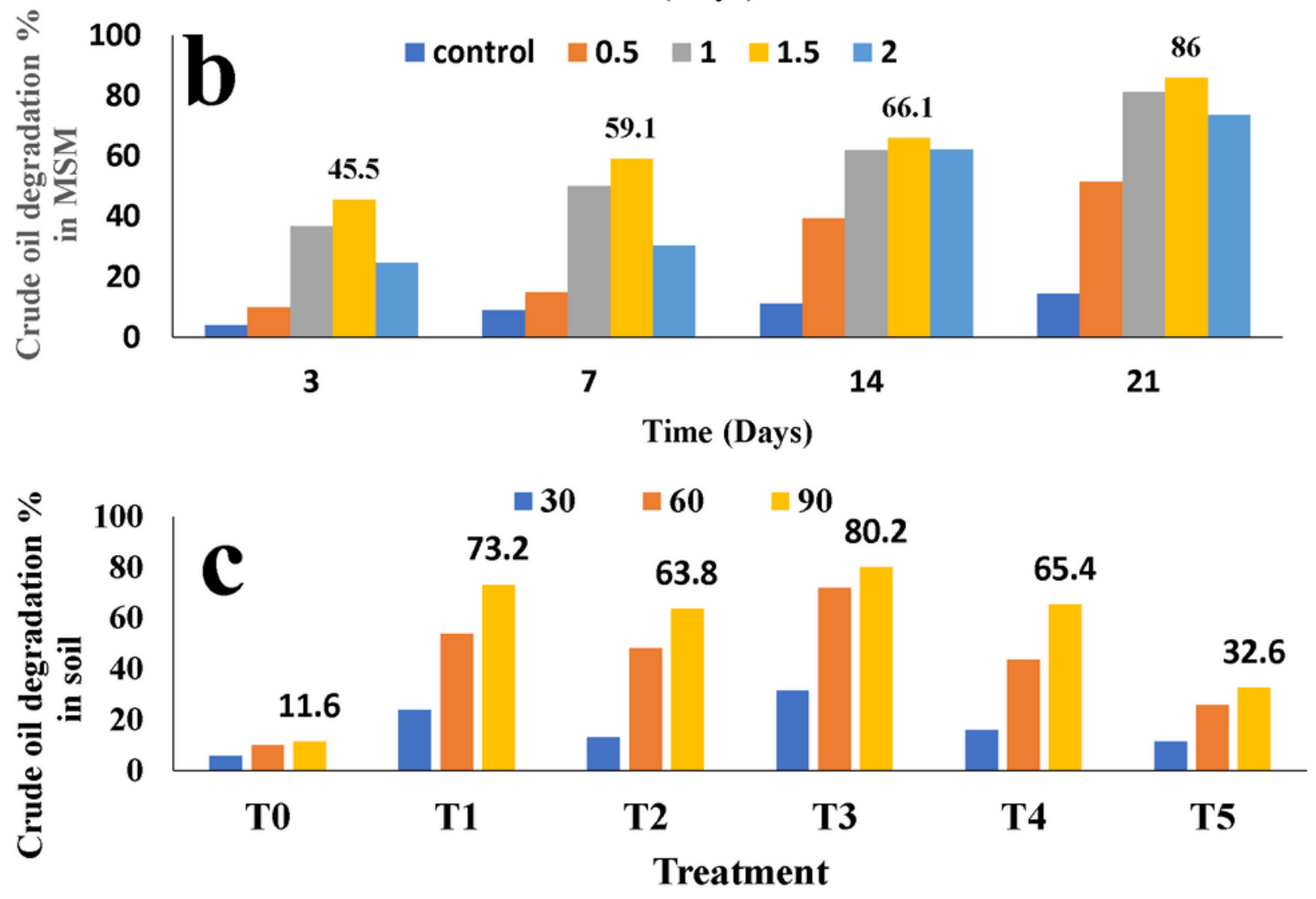

Figure 10

The growth of (a) Bacillus subtilis SNW3 on crude oil and MSM with surface tension reduction values for 21 days and (b) quantity of crude oil degraded (\%) by Bacillus subtilis SNW3 for 21 days at different intervals in MSM and (c) (\%) degradation for 90 days in crude oil contaminated soil. 


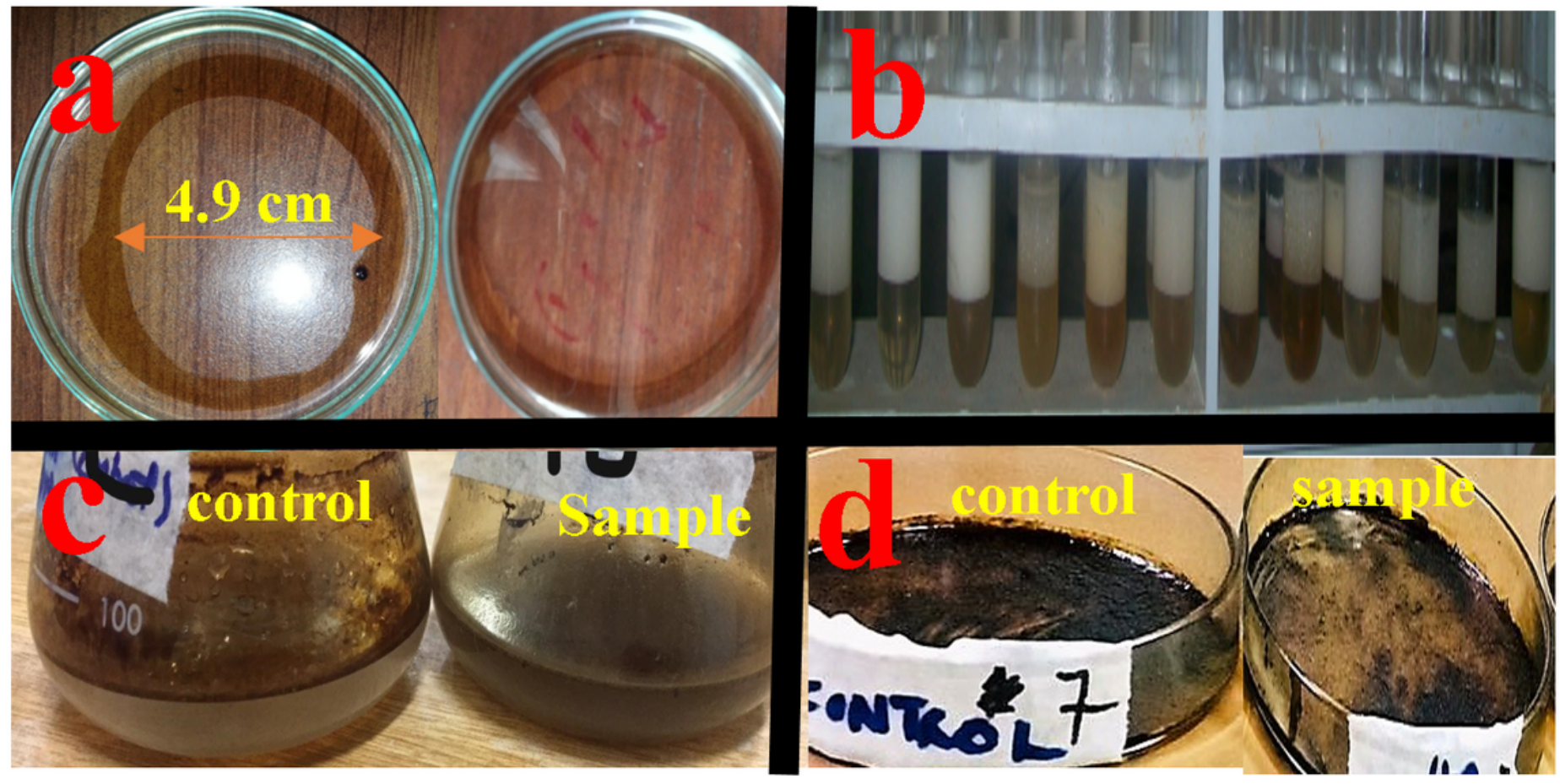

Figure 11

Testing of surfactin for (a) oil displacement activity in crude oil, (b) Emulsification activity (E24 up to $70 \%$ ) (c) screening of Bacillus subtilis SNW3 for bioremediation of crude oil in uninoculated control and sample with $1 \%$ crude oil after 21 days (d) extraction of crude oil with hexane after 21 days from uninoculated control and $1 \%$ crude oil sample by gravimetric analysis.

\section{Image not available with this version}

Figure 12 
Schematic diagram showing bacterial strain activity in degradation of crude oil recalcitrant hydrocarbons with simultaneously surfactin production.

\section{Supplementary Files}

This is a list of supplementary files associated with this preprint. Click to download.

- Supplementarydata1.pdf 